Portland State University

PDXScholar

Sociology Faculty Publications and

Presentations

Sociology

$10-2021$

\title{
Field-Specific Cultural Capital and Persistence in College Majors
}

Ned William Tilbrook

Portland State University, ned.tilbrook@gmail.com

Dara Shifrer

Portland State University, dshifrer@pdx.edu

Follow this and additional works at: https://pdxscholar.library.pdx.edu/soc_fac

Part of the Sociology Commons

Let us know how access to this document benefits you.

\section{Citation Details}

Published as: Tilbrook, Ned, and Dara Shifrer. 2021. "Domain-Specific Cultural Capital and Persistence in College." Social Science Research, Published online first.

This Post-Print is brought to you for free and open access. It has been accepted for inclusion in Sociology Faculty Publications and Presentations by an authorized administrator of PDXScholar. Please contact us if we can make this document more accessible: pdxscholar@pdx.edu. 
Tilbrook, Ned, and Dara Shifrer. 2021. "Domain-Specific Cultural Capital and Persistence in College." Social Science Research Published online first.

\section{Field-Specific Cultural Capital and Persistence in College Majors}

Ned Tilbrook and Dara Shifrer

Portland State University, Department of Sociology

Abstract. We investigate the possibility that Bourdieu's concept of cultural capital, ways of being that facilitate assimilation to the dominant culture, is field-specific in its manifestation and intergenerational transmission. We focus on a field of central economic and academic interest: STEM. Data on around 13,000 undergraduates from the large nationally representative High School Longitudinal Study of 2009 indicate that parents' STEM-specific cultural capital positively contributes to youth's selection of and persistence in STEM majors in the form of parents' STEM education. We find that transmission is enacted through youths' field-specific institutionalized cultural capital (e.g., STEM grades and test scores), field-specific embodied cultural capital (e.g., STEM attitudes), and characteristics of their educational institutions (e.g., four-year rather than two-year college). This study contributes to the theory of cultural capital by examining cultural capital through a field-specific lens, and then specifically elucidating how it is expressed and transmitted within that field.

Keywords: Cultural Capital, College Major, Academic Attitudes, Academic Achievement, School Context

Accepted Manuscript version published online first in Social Science Research (https://doi.org/10.1016/j.ssresearch.2021.102654). Direct all correspondence to Ned Tilbrook, Portland State University, Department of Sociology, 1721 SW Broadway Ave, Portland, OR 97201 (email: til@ pdx.edu). This research is funded by the National Science Foundation (DRL1652279) and by the National Institutes of Health funded Build EXITO program at Portland State University (UL1GM118964). This paper benefits from suggestions from CJ Appleton, Emily Burgess, Hannah Sean Ellefritz, Sarah Florig, Tristen Kade, Sarah Kyte, Daniel Mackin Freeman, Byeongdon Oh, Luke Robinowitz, Phillip Willis, Jaime Wood, Tian Wu, and Kaitlin Yeomans.

1 (C)2021. This manuscript version is made available under the CC-BY-NC-ND 4.0 license https://creativecommons.org/licenses/by-nc-nd/4.0/ 


\section{Tilbrook, Ned, and Dara Shifrer. 2021. "Domain-Specific Cultural Capital and Persistence in College." Social Science Research Published online first.}

\section{Introduction}

The theoretical work of Pierre Bourdieu $(1977,1984,1986)$ on cultural capital is influential in the sociology of education, and stratification research more broadly (Davies and Rizk 2018; Jaeger 2011; Laanan, Starobin, and Eggleston 2010; Lamont and Lareau 1988; Lareau 2003; Lareau, Evans, and Yee 2016). Scholars are interested in how cultural capital, that is the cultural resources recognized as correct by gatekeepers, relates to educational attainment and how it is passed down from one generation to the next. This body of research highlights the mechanisms underlying educational inequalities that remain entrenched in the US and are reproduced through generations.

Cultural capital theory, however, has faced criticism. For one, it is defined in different ways, and can be difficult to operationalize and measure. Its relevance in the US context is also questioned, where there may not be a coherent 'elite' culture that is consistently recognized and rewarded in educational and occupational institutions (Jaeger 2011; Kingston 2001; Lareau 2003). More recent research tries to address this issue by focusing on Bourdieu's (1984) social 'field,' that is, any system of social positions in which individuals vie for resources. With the cultural resources that are recognized as dominant cultural capital more clear and consistent (Lareau et al. 2016; Starobin, Smith, and Laanan 2016), focusing on a specific field facilitates a more coherent and tangible operationalization of cultural capital. More importantly, this more specific focus ultimately supports the specification and nuancing of the broader cultural capital theory. Future research can build on our findings to draw parallels as to what constitutes dominant cultural capital in other fields, and then these contextualized findings can be considered in tandem to build a richer and more tangible framework for cultural capital theory in the US.

2 (2021. This manuscript version is made available under the CC-BY-NC-ND 4.0 license https://creativecommons.org/licenses/by-nc-nd/4.0/ 


\section{Tilbrook, Ned, and Dara Shifrer. 2021. "Domain-Specific Cultural Capital and Persistence in College." Social Science Research Published online first.}

In this study, we focus on the social field of $\operatorname{STEM}^{1}$ education. We theorize that parents who have field-specific cultural capital in STEM may transmit advantages in STEM-specific cultural capital to their offspring, making their offspring more likely to intend a STEM major and persist in that major than the offspring of parents without STEM-specific cultural capital. We use data on around 12,000 young adults from a large and nationally representative dataset, the High School Longitudinal Study of 2009. Our analytic focus on the educational field of STEM capitalizes on this dataset's particular focus on STEM. We ask the following research questions: 1) How does parental field-specific cultural capital (i.e., their STEM education and occupations) relate to young adults' selection of and persistence in STEM majors? 2) Which measures of youth's STEM-specific embodied and institutionalized cultural capital, as well as the characteristics of their educational institutions, mediate any relationship between parents' STEM-specific cultural capital and youths' postsecondary STEM-major outcomes? With HSLS the most recently available federal education data, we are able to longitudinally track the cohort from the first wave of data collection (2009), when they were in the ninth grade, through three years past high school for most of the sample (2016). In addition to considering parents' fieldspecific cultural capital, this rich data facilitates our consideration of offspring's field-specific embodied cultural capital (e.g., STEM-positive attitudes), field-specific institutionalized cultural capital (e.g., end of high school STEM achievement), and the social processes whereby parents help to build their offspring's embodied and cultural capital (e.g., field-specific cultural capital building activities, targeted selection of educational institutions). Ultimately, we contribute to the

${ }^{1}$ STEM=science, technology, engineering, and mathematics.

3 (2021. This manuscript version is made available under the CC-BY-NC-ND 4.0 license https://creativecommons.org/licenses/by-nc-nd/4.0/ 


\section{Tilbrook, Ned, and Dara Shifrer. 2021. "Domain-Specific Cultural Capital and Persistence in College." Social Science Research Published online first.}

theory of cultural capital by examining cultural capital through a field-specific lens, and then specifically elucidating how it may be expressed and transmitted within that field.

\subsection{Towards a Field-Specific Understanding of Cultural Capital}

Cultural capital, a theory first proposed by French sociologist Pierre Bourdieu (1977, 1986), demonstrates how differences in social mobility partially result from the actual and perceived value of persons' cultural resources. Bourdieu elaborates on the forms and processes of cultural capital: embodied cultural capital refers to an individual's knowledge and practices that signal cultural capital to others in social interactions, whereas institutionalized cultural capital refers to the accumulation of cultural capital through institutionally-recognized items such as degrees, or things that signal cultural competence or authority (Bourdieu 1986). The cultural resources that are valued and rewarded in schools and the workplace - that is, certain ways of being and talking, and common understandings — reflect the dominant culture (Bourdieu 1986). Therefore, children from families with higher socioeconomic status arrive at school in possession of cultural capital that will be rewarded: they are perceived more positively in school, are better able to access educational goods, and ultimately progress to and prosper in the occupational spaces that confer status and power.

Bourdieu's ideas, though influential, are criticized for lacking conceptual clarity. First, early US cultural capital research focused on familiarity with high culture, using measures such as museum visits as indicators of cultural capital (DiMaggio 1982; DiMaggio and Mohr 1985), yet these studies did not delineate how knowledge of fine arts is recognized and rewarded by teachers or the education system (Davies and Rizk 2018; Kingston 2001; Lamont and Lareau 1988). More recent cultural capital research focuses on class differences in parenting styles, finding that middle-class parents engage in 'concerted cultivation,' i.e., active efforts to shape

4 (2021. This manuscript version is made available under the CC-BY-NC-ND 4.0 license https://creativecommons.org/licenses/by-nc-nd/4.0/ 


\section{Tilbrook, Ned, and Dara Shifrer. 2021. "Domain-Specific Cultural Capital and Persistence in College." Social Science Research Published online first.}

and develop their children, whereas working-class parents allow their children to develop through 'natural growth parenting' (Lareau 2011; Lareau et al. 2016). Cultural capital theory is also critiqued for not clearly articulating whether cultural capital includes both noncognitive (e.g., attitudes, behaviors) and cognitive (e.g., achievement) resources (Jaeger 2011; Kingston 2001; Lareau and Weininger 2003; Sullivan 2001). Lareau and Weininger (2003) argue that Bourdieu believed cultural capital and cognitive skills to be inseparable as the first is innately tied to the development of the second.

Farkas $(2003,2018)$, in contrast, suggests cultural capital should be operationalized as academic work habits that are recognized as correct by teachers, such as good organizational skills and emotional stability. In this framing of cultural capital, teachers act as gatekeepers, rewarding academic work habits they recognize as correct. In the immediate sense, teachers may reward students by giving them more challenging work and subsequently building their cognitive skills, or by providing positive feedback which builds students' self-efficacy and educational aspirations, and thus their embodied cultural capital. In the longer term, rewards for dominant cultural capital within educational institutions takes the form of good grades, higher test scores, and ultimately degrees, that is, institutionalized cultural capital. In this way embodied cultural capital is, in time, transformed into institutionalized cultural capital. With the process dynamic and cyclical, the accumulation of institutionalized cultural capital subsequently builds embodied cultural capital, ultimately ensuring the advantages of youth with dominant cultural capital are reproduced.

Recent cultural capital scholarship focuses on field-specific ways in which cultural capital is accumulated and used. Bourdieu described the social 'field' as the space where cultural resources are recognized as cultural capital. A field represents any social setting in which there is

5 (2021. This manuscript version is made available under the CC-BY-NC-ND 4.0 license https://creativecommons.org/licenses/by-nc-nd/4.0/ 


\section{Tilbrook, Ned, and Dara Shifrer. 2021. "Domain-Specific Cultural Capital and Persistence in College." Social Science Research Published online first.}

a system of social positions in which individuals vie for resources (Bourdieu 1984). Importantly, the cultural resources recognized as cultural capital may vary depending on the social field. For example, years of experience at a particular workplace might be valued within the 'field' of that organization, representing a familiarity with the work and culture of the organization, but might not be valued as cultural capital in other organizations. Similarly, the practices teachers recognize as cultural capital in the field of the school, such as raising a hand before speaking, may not represent cultural capital during interactions with peers after school. Even within school, different ingrained tendencies and attitudes may be rewarded in different classrooms. For example, the tendency towards creativity is a cultural resource that might be recognized as cultural capital in an arts classroom, but not in a math classroom.

In an example of recent scholarship, 'transfer student capital' describes the cultural resources community college students employ to facilitate their transfer to four-year institutions (Laanan et al. 2010; Starobin et al. 2016). A handful of scholars have also focused on cultural capital specific to the STEM field (Starobin et al. 2016; Stolle-McAllister 2011), reflecting concerns about a deficit of STEM-skilled young people relative to the number of STEM jobs in the US economy (Chen and Soldner 2013; Gonzalez and Kuenzi 2012). These scholars build on the idea that disparities in STEM cognitive and non-cognitive resources, that are clearly evident by high school, can be traced back to early life experiences (Andersen and Ward 2014; Morgan et al. 2016; Saw, Chang, and Chan 2018). This field-specific operationalization is useful in cultural capital research as it narrows the focus on which cultural resources are valued and rewarded, thereby increasing the likelihood of tangible conceptualizations of cultural capital Moreover, by simultaneously accounting for the fact that cultural capital is variable across different social fields, field-specific research builds a more nuanced and specific framework for

6 (2021. This manuscript version is made available under the CC-BY-NC-ND 4.0 license https://creativecommons.org/licenses/by-nc-nd/4.0/ 
Tilbrook, Ned, and Dara Shifrer. 2021. "Domain-Specific Cultural Capital and Persistence in College." Social Science Research Published online first.

cultural capital theory writ large. In this article, we study cultural capital in the social field of STEM education.

\subsection{Intergenerational Transmission of STEM-Specific Cultural Capital}

Figure 1 draws on existing conceptualizations of cultural capital to illustrate our theoretical model of how STEM-specific cultural capital manifests, is transmitted across generations, and accrues. We first identify characteristics that may signal a parent has STEMspecific cultural capital and thus can create a home environment conducive to their offspring building cultural capital specific to this field. Parents' degrees more generally help parents transmit knowledge about higher education to their children (Gayo 2016; Stephens et al. 2015; Yee 2016), but parents with bachelor's degrees in a STEM major may be particularly well situated to communicate the value of STEM majors and to prepare their child for common barriers along the way (e.g., gatekeeping courses). Research shows that many young people lack knowledge on STEM careers (Schneider et al. 2013; Zavrel 2011), and parents with STEM occupations may be better prepared to demystify STEM occupations for their child, communicating the nature of the work or strategies for achieving employment. They might broaden understanding of common ways of being and behaving in STEM-specific environments. STEM occupations are particularly perceived as difficult or intimidating (Turner et al. 2017; Zavrel 2011), but may seem less so for the children of parents who work in STEM fields. With some previous evidence suggesting youth who have a parent in a STEM occupation are more likely to aspire to a STEM career (Holmes et al. 2018), we more specifically expect that parents transmit STEM-specific cultural capital to their children by fostering a home environment that values STEM, thereby ingraining the values, attitudes, and academic work habits needed to succeed in STEM fields. These parents may be more likely to take their children to scientific

7 C2021. This manuscript version is made available under the CC-BY-NC-ND 4.0 license https://creativecommons.org/licenses/by-nc-nd/4.0/ 


\section{Tilbrook, Ned, and Dara Shifrer. 2021. "Domain-Specific Cultural Capital and Persistence in College." Social Science Research Published online first.}

museums and to engage in conversations on scientific topics. Based on previous research focused on non-field-specific cultural capital (Lareau 2003, 2011), they may encourage their children to engage in math- and science-focused extracurricular activities. Parents with STEM-specific cultural capital may build their child's informal scientific knowledge, as well as their selfefficacy and value for math and science, forms of embodied cultural capital that an adolescent or young adult can deploy in a classroom setting in order to signal to their teacher or professor their shared value for and understanding of STEM fields.

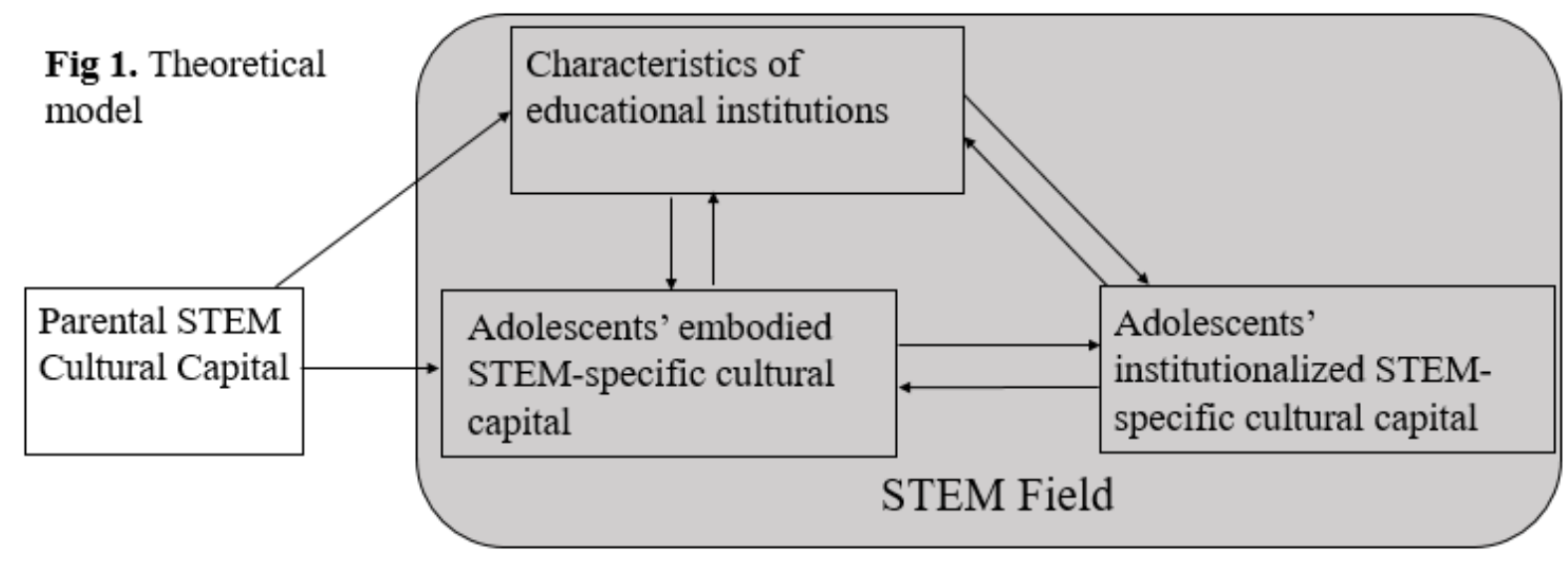

Parents may also transmit STEM-specific cultural capital through the educational institutions they select for their children. Parents with STEM-specific cultural capital may send their adolescent to a private rather than public high school, in hopes of exposing them to enriched curriculum, more equitable tracking practices, and strategic social networks (Carbonaro and Covay 2010; Cookson and Persell 1985; Hoffer, Greeley, and Coleman 1985; Morgan and Todd 2009). However, other, more recent, studies find that any private school advantage disappears after accounting for differences in student social background (Lubienski and Lubienski 2013; Pianta and Ansari 2018). Research also shows that religious schools do not

8 (2021. This manuscript version is made available under the CC-BY-NC-ND 4.0 license https://creativecommons.org/licenses/by-nc-nd/4.0/ 


\section{Tilbrook, Ned, and Dara Shifrer. 2021. "Domain-Specific Cultural Capital and Persistence in College." Social Science Research Published online first.}

perform well in terms of student science achievement (Lubienski and Lubienski 2013).

Differences across colleges (e.g., sector, selectivity) are central for major persistence (Engberg and Wolniak 2013), and reflect both parental intervention and institutional rewards for an adolescent's institutionalized cultural capital. In addition to structural differences, these characteristics of colleges may represent distinct student climates that reinforce STEM-specific knowledge, values, and skill building.

Young adults begin the process of choosing a major before they have entered college, as they experience varying levels of success in and identification with different subjects (Andersen and Ward 2014; Saw et al. 2018), experiences that also shape their field-specific self-efficacy (Moakler and Kim 2014; Wang 2013). Like self-efficacy and identity, believing that tasks in a certain field align with your goals (utility value) predicts selecting a major in that field (Holmes et al. 2018; Rozek et al. 2017; Shoffner et al. 2015; Wang 2013). Extra-curricular activities can also develop this embodied cultural capital, as well as knowledge that facilitates institutionalized cultural capital (Bulunuz, Bulunuz, and Peker 2014; Morris 2016). The factors that lead young adults to select STEM majors (e.g., their parents' STEM-specific cultural capital, and their own STEM-specific embodied and institutionalized cultural capital) may also facilitate their persistence in STEM majors (Holmes et al. 2018; Rozek et al. 2017; Wang 2013); accumulation of this field-specific cultural capital then facilitates the accumulation of further institutionalized STEM capital by increasing students' chances of enrollment in university programs within those field, and into potentially more prestigious university programs. Although persistence in a STEM major will partially reflect postsecondary factors we cannot measure, previous research suggests that persistence in STEM majors also reflects young adults' early attitudes and achievement experiences that represent powerful early forces of socialization (Griffith 2010; Riegle-Crumb,

9 (2021. This manuscript version is made available under the CC-BY-NC-ND 4.0 license https://creativecommons.org/licenses/by-nc-nd/4.0/ 
Tilbrook, Ned, and Dara Shifrer. 2021. "Domain-Specific Cultural Capital and Persistence in College." Social Science Research Published online first.

King, and Irizarry 2019; Riegle-Crumb, King, and Moore 2016). Ultimately, we focus on two research questions:

\section{Research Questions}

1) How does parents' STEM-specific cultural capital relate to adolescents' selection of and persistence in STEM majors?

2) Which potential measures of youth's STEM-specific embodied and institutionalized cultural capital, STEM-specific cultural capital building activities, as well as the characteristics of their educational institutions, mediate any relationship between parents' STEM-specific cultural capital and youth's postsecondary STEM-major outcomes?

\section{Data and Methods}

We use data from the High School Longitudinal Study of 2009, which is administered by the National Center for Education Statistics. This is a large, nationally representative dataset with over 21,000 participants who were in the 9th grade in 2009 (Wave 1). Most sampled adolescents were in their junior year during Wave 2 (2012), had just finished high school by Wave 3 (2013), and were three years out of high school by Wave 4 (2016). We use data from the Wave 1 parent, student, and school administrator surveys; the Wave 2 student surveys; the Wave 3 transcript data and NCES test scores; and the Waves 3 and 4 student surveys. We have two analytic samples. Our first, the Intending College Analytic Sample, includes all students who indicated an intention to attend college and who are not missing on the dependent variable, major selection $(\mathrm{n}=12,730)$. The Intended STEM Major Analytic Sample includes those in the first analytic sample who indicated their first major was in a STEM field and who are not missing on the second dependent variable, major persistence $(n=3,250)$. Variables have between $0 \%$ and $34 \%$ of cases missing, with missingness highest on household income. We used a categorical measure of license https://creativecommons.org/licenses/by-nc-nd/4.0/ 


\section{Tilbrook, Ned, and Dara Shifrer. 2021. "Domain-Specific Cultural Capital and Persistence in College." Social Science Research Published online first.}

income (with a missing rate of $22 \%$ ) to help account for this during imputation. All other variables had missing rates below $21 \%$. We account for missing values on independent variables through multiple imputation using the MICE system of chained equations (White, Royston, and Wood 2011). As specified in the HSLS users' guide (Duprey et al. 2018), we use Stata's survey procedure to apply the student-level panel weight, to adjust for students being clustered in high schools, and to account for HSLS's complex survey design.

\subsection{Dependent Variables}

Our dependent variables are dichotomous measures of STEM major selection and persistence. The major selection variable focuses on the type of major the student was intending upon entry (Wave 3, the summer after high school). The dichotomous persistence variable measures if students who were initially intending a STEM major report that, as of February 2016 (Wave 4), they are still studying a STEM major; we set students who switched into a non-STEM major or who dropped out of college to zero. Additionally, we code students who did not indicate a current major because they had finished their degree as having persisted. There is debate as to which fields should be considered STEM fields. For example, while the National Science Foundation excludes applied fields such as nursing (National Science Foundation 2019), the Bureau of Labor Statistics includes nursing (Hedgecock 2016). Because of this debate and distinctions that emerged in our exploratory analyses with HSLS data, we include social science majors but exclude applied healthcare majors. These exploratory analyses consist of descriptive statistics (Online Tables 1, 3, and 5) and logistic regression models (Online Tables 2, 4, and 6) predicting majoring in social sciences, science and engineering, and healthcare majors. Because we find that parents' STEM-specific cultural capital relates similarly to social sciences and core license https://creativecommons.org/licenses/by-nc-nd/4.0/ 
Tilbrook, Ned, and Dara Shifrer. 2021. "Domain-Specific Cultural Capital and Persistence in College." Social Science Research Published online first.

STEM (physical science, engineering, math) majors but differently to healthcare majors, we use the NSF definition of STEM (which excludes healthcare) (Hedgecock 2016).

\subsection{Predictors of Interest}

Our two predictors of interest, parents' STEM-specific cultural capital, are drawn from the base year parent survey data. Our parental occupation measure of field-specific cultural capital is coded 1 if the student has at least one parent in a STEM occupation and 0 if not. We then construct a three-category variable to measure field-specific cultural capital in terms of parental education: 0 if neither parent has a bachelor's degree, 1 if at least one parent has a bachelor's but neither parent has a bachelor's in a STEM field, and 2 if at least one parent has a bachelor's in a STEM field. As we would expect, these measures do covary. In the Intending College Analytic Sample, 35\% percent of students who have a parent with a STEM degree also have a parent in a STEM occupation and 53\% of students with a parent in a STEM occupation also have a parent with a STEM degree. This means that $6 \%$ of this sample have both a parent with a STEM occupation and a STEM degree. These figures are respectively $43 \%$ and $70 \%$ in the Intended STEM Major Analytic Sample, meaning that $10 \%$ of this sample have both a parent with a STEM occupation and a parent with a STEM degree.

\subsection{Mediators}

Our first set of mediators focus on adolescents' STEM-specific cultural capital building activities. These include two dichotomous measures of whether parents report in the Wave 1 survey that they took their adolescent to a science/engineering museum or discussed a STEMrelated documentary or article with their adolescent in the last year. The two other dichotomous indicators measure whether the student reports participating in any organized extra-curricular activities (competitions, clubs, camp, and tutoring) in math and science at Wave 1.

12 (C)21. This manuscript version is made available under the CC-BY-NC-ND 4.0 license https://creativecommons.org/licenses/by-nc-nd/4.0/ 


\section{Tilbrook, Ned, and Dara Shifrer. 2021. "Domain-Specific Cultural Capital and Persistence in College." Social Science Research Published online first.}

Our second set of mediators capture adolescents' STEM-specific embodied cultural capital. These first include four continuous scale measures of high school attitudes toward math and science (based on respondents' Wave 2 reports). Our exploratory analyses did not find empirical support for the attitudinal scales constructed by NCES (identity, interest, self-efficacy, and utility value). Rather, we determined many of the survey items measured the same latent factor despite wording that might indicate otherwise. Ultimately, the math- and science-specific scales with the highest inter-item correlation measured self-efficacy/identity and utility value (relates well to goals). Although some survey items used for the self-efficacy/identity scales seem to be measuring STEM interest, we name the scale to reflect the majority of the survey items used. All alpha coefficients are greater than 0.70 . We recode variables to all range from 0 to 3 so that all contribute equally to the scale after averaging $(0,1,2$, and 3 represent different levels for variables focused on agreement or frequency, whereas 0 represents 'no' and 3 represents 'yes' for dichotomous variables). See Appendix A for a full list of survey items used to construct each attitudinal scale used in this study. We set scales to missing for respondents missing on even just one of the survey items used to construct the scale, as bias is a likely result of constructing “pro-rated” scales (Mazza, Enders, and Ruehlman 2015). These variables are all standardized to increase interpretability and comparability. Finally, we include respondents' Wave 2 dichotomous reports of whether they expect a STEM occupation by age 30, and Wave 4 dichotomous reports of whether they chose their current major because they did well in the courses for that major, or because they were encouraged by someone to take that major, potentially indicating a confidence in their own abilities and their awareness that low grades are common in STEM gatekeeping classes.

13 C2021. This manuscript version is made available under the CC-BY-NC-ND 4.0 license https://creativecommons.org/licenses/by-nc-nd/4.0/ 


\section{Tilbrook, Ned, and Dara Shifrer. 2021. "Domain-Specific Cultural Capital and Persistence in College." Social Science Research Published online first.}

Our third set of mediators capture adolescents' STEM-specific institutionalized cultural capital. We use transcript data to construct measures of math and science field course attainment by the end of high school. We measure math course attainment with a dichotomous measure of whether the student advanced beyond algebra II in high school, the level typically required for admission to a four-year college (Riegle-Crumb and Grodsky 2010). We dichotomously measure science course attainment in terms of whether the student earned at least one high school physics credit. NCES used transcript data to construct a continuous measure of high school STEM grade point average (GPA). Finally, we use the standardized version of respondents' score on the math test administered by NCES during Wave 2, when most were in their junior year (math is the only subject tested).

Finally, we consider the characteristics of respondents' educational institutions as potential mediators, hypothesizing that educational institutions vary depending on parents' STEM-specific cultural capital and building on the previous literature that suggest educational institutions differentiate STEM-major-outcomes. First, we categorically measure the sector (public, Catholic, non-Catholic private) of the high school the adolescent attended at Wave 1, when they were in the ninth grade. We include a dichotomous measure of whether the first college attended is not a four-year institution, a three-category measure of college sector (public, private non-profit, and private for-profit), and an ordinal measure of college selectivity (nonselective, moderately selective, and highly selective).

\subsection{Controls}

We use Wave 1 measures from the student survey to control for respondents' race and gender. We collapse the race variable into five categories: White, Black, Latinx, Asian, and other. We also use a continuous measure of household income from the Wave 1 parent survey.

14 (2021. This manuscript version is made available under the CC-BY-NC-ND 4.0 license https://creativecommons.org/licenses/by-nc-nd/4.0/ 


\section{Tilbrook, Ned, and Dara Shifrer. 2021. "Domain-Specific Cultural Capital and Persistence in College." Social Science Research Published online first.}

\subsection{Analytic Plan}

We estimate descriptive statistics for both analytic samples. To understand how parental STEM-specific cultural capital relates to major selection, we use the Intended College Analytic Sample to estimate a logistic regression model predicting initially intending a STEM major. To understand how parental STEM-specific capital relates to major persistence, we use the Intended STEM Major Analytic Sample to estimate a logistic regression model predicting persisting in a STEM major. Each of these models include the measures of parents' STEM-specific cultural capital and the control variables.

To understand the mechanisms whereby parental STEM-specific cultural capital relates to major pursuits, we use bivariate analyses to establish how the parental STEM-specific cultural capital predictors relate to the potential mediators, and then how the potential mediators relate to the dependent variables (major selection and persistence). These descriptive statistics facilitate interpretation of the actual mediation analyses, which rely on Stata's KHB command, a technique developed by Kohler, Karlson, and Holm (2011). Importantly, this method was specifically designed to adjust for the issues of scaling that arise when attempting to compare coefficients across logistic regression models (a dated approach to understanding mediation) (Kohler et al. 2011). This decomposition technique, based in regression modelling, uses percentage rather than coefficients to show the degree to which the relationship is explained by each mediator, numbers that are more easily understood and more evocative of substantive significance (Healy and Moody 2014). We use the KHB command to examine only relationships shown to be statistically significant in the logistic regression models. The KHB model predicting STEM-major persistence include all potential mediators, whereas the KHB model predicting STEM-major intentions excludes potential mediators that occur after students are forming their

15 (2021. This manuscript version is made available under the CC-BY-NC-ND 4.0 license https://creativecommons.org/licenses/by-nc-nd/4.0/ 


\section{Tilbrook, Ned, and Dara Shifrer. 2021. "Domain-Specific Cultural Capital and Persistence in College." Social Science Research Published online first.}

major intentions. Because end of high school achievement, a marker of institutionalized STEM cultural capital, is highly correlated with college major outcomes, it would not be surprising if these measures contribute more to the relationship between parents' STEM-specific cultural capital and youths' STEM-major outcomes than other potential mediators. Thus, we estimate a second set of KHB models that re-conceptualize the measures that contributed the most in the first set of KHB models as outcome variables, only including predictors that temporally make sense as potential mediators (i.e., occur later in time than parents' STEM-specific cultural capital but before the outcome of interest). In this way, we establish temporally ordered correlational links that demonstrate how parents imbue their children with STEM-specific embodied cultural capital and choose certain educational institutions, which in turn facilitates the accumulation of STEM-specific institutionalized cultural capital.

\section{Results}

\subsection{Descriptive Statistics}

Table 1 provides descriptive statistics for all variables used in this study. In the Intending College Analytic Sample, $28 \%$ intended to major in a STEM field when in college. The Intending STEM Major Analytic Sample shows that $64 \%$ persisted with a STEM major. Twelve percent of the Intending College Analytic Sample have a parent with a STEM occupation; this proportion is $15 \%$ within the Intending STEM Major Analytic Sample. Fifty-five percent of the Intending College Analytic Sample have no parent with a bachelor's degree; $27 \%$ have a parent with a nonSTEM bachelor's degree and 18\% have a parent with a STEM bachelor's. Within the Intending STEM Major Analytic Sample, $47 \%$ of students have no parent with a bachelor's degree, while $29 \%$ have a parent with a non-STEM bachelor's degree and 24\% have a parent with a STEM license https://creativecommons.org/licenses/by-nc-nd/4.0/ 


\section{Tilbrook, Ned, and Dara Shifrer. 2021. "Domain-Specific Cultural Capital and Persistence in College." Social Science Research Published online first.}

bachelor's degree. Consistent with this study's underlying assumptions, the proportion of students whose parents hold STEM-specific cultural capital is higher among the Intending STEM Major Analytic Sample than among the Intending College Analytic Sample.

\subsection{Parents'STEM-Specific Cultural Capital and Youth's STEM Major Outcomes}

Table 2 shows results from logistic regression models examining how parents' STEMspecific cultural capital relates to youths' STEM-major outcomes. Model 1 uses the Intending College Analytic Sample to predict intending a STEM major. The odds of intending a STEM major are $18 \%$ higher on average for those who have a parent in a STEM occupation relative to those who do not; however, this relationship is not statistically significant. Model 1 also shows that the odds of intending a STEM major are 37\% higher on average for those who have a parent with a non-STEM bachelor's degree, but 79\% higher on average for those who have a parent with a STEM bachelor's degree (both compared to youth without a parent with a bachelor's degree). These associations are statistically significant. The seemingly larger estimated effect of having a parent with a bachelor's degree in a STEM field, relative to having a parent with a bachelor's degree in some other field, particularly suggests that some cultural resources may be field-specific.

Model 2 in Table 2 uses the Intended a STEM Major Analytic Sample to predict persisting in a STEM major. Having a parent in a STEM occupation is associated with an average odds increase of $18 \%$; this is not statistically significant. The average odds of persisting in a STEM major are $41 \%$ higher on average for youth with a parent with a non-STEM bachelor's degree relative to the odds for youth who do not have a parent with a bachelor's degree. However, the benefit of a parents' bachelor's degree is nearly twice as high if it is in STEM, with young adults' odds of persisting in a STEM major 107\% higher on average. Both of

17 C2021. This manuscript version is made available under the CC-BY-NC-ND 4.0 license https://creativecommons.org/licenses/by-nc-nd/4.0/ 


\section{Tilbrook, Ned, and Dara Shifrer. 2021. "Domain-Specific Cultural Capital and Persistence in College." Social Science Research Published online first.}

these relationships are statistically significant. While these findings again suggest parents' educational cultural capital may be field-specific, parental STEM occupations, never statistically significant, does not appear to function as field-specific cultural capital. We therefore only use decomposition analysis to examine the mediators in the relationship between parental educational cultural capital and young adults' STEM major intentions and persistence.

\subsection{Intergenerational Transmission of STEM-Specific Cultural Capital}

Tables 3 presents the results of bivariate analyses between parents' educational cultural capital and the mediator variables, in order to build a foundation for interpreting the decomposition-mediation analyses. Adolescents who do not have a parent with a bachelor's degree have the lowest level of participation in STEM-specific cultural capital building activities, while adolescents who have a parent with a STEM degree have the highest levels of participation. With the exception of math utility value, adolescents who have no parent with a bachelor's exhibit the lowest levels of STEM-specific embodied cultural capital (i.e., high school STEM-positive attitudes), whereas adolescents who have a parent with a STEM bachelor's degree exhibit the highest levels. Patterns are similar in terms of adolescents' STEM-specific institutionalized cultural capital (i.e., end of high school STEM achievement). Adolescents without a parent with a bachelor's degree are more likely to attend public rather than private high schools than adolescents whose parents have a non-STEM or STEM bachelor's degree. In terms of four- versus two-year, sector, and selectivity, the colleges young adults who have a parent with a STEM degree attend are the most prestigious whereas the colleges young adults who have no parent with a bachelor's degree are the least prestigious. Overall, findings suggest that youth with parents with STEM-specific educational cultural capital experience more STEM-specific

18 (C)2021. This manuscript version is made available under the CC-BY-NC-ND 4.0 license https://creativecommons.org/licenses/by-nc-nd/4.0/ 


\section{Tilbrook, Ned, and Dara Shifrer. 2021. "Domain-Specific Cultural Capital and Persistence in College." Social Science Research Published online first.}

cultural-capital building activities, exhibit more STEM-specific embodied and institutionalized cultural capital, and are the most advantaged in terms of the educational institutions they attend.

Table 4 show results from decomposition analyses to determine which of these differences actually mediate the relationships between parents' STEM-specific educational cultural capital and their offspring's STEM major intentions and persistence. This method adjusts the contribution of each mediator (expressed as a percentage in the rightmost columns) for the related influence of all other mediators and controls included in the model. We focus on mediators that explain $5 \%$ or more of the relationship.

Model 1 in Table 4 shows that youth's high school math test scores are the largest mediator of the relationship between their parents' educational cultural capital and the likelihood that they intend a STEM major. With higher math test scores relating positively to the likelihood of intending a STEM major (the first column under Model 1), differences in math test scores explain $31 \%$ of this relationship, after accounting for related differences in other potential mediators and controls. With a higher high school STEM GPA also relating positively to intending a STEM major, differences in youth's high school STEM GPA explain 16\% of the same relationship. Both relating positively to STEM major intentions, differences by parents' educational cultural capital in expecting a STEM occupation at age 30 and in completing high school physics respectively account for $11 \%$ and $8 \%$ of the relationship between parents' educational cultural capital and their offspring's intentions to major in STEM. STEM-specific embodied cultural capital Model 2 in Table 4 shows that measures of youth's STEM-specific institutionalized cultural capital are also key mediators of the relationship between parents' educational cultural capital and their offspring's likelihood of persisting in a STEM major. Differences in high school STEM GPA accounts for $45 \%$ of this relationship, differences in math

19 (2021. This manuscript version is made available under the CC-BY-NC-ND 4.0 license https://creativecommons.org/licenses/by-nc-nd/4.0/ 


\section{Tilbrook, Ned, and Dara Shifrer. 2021. "Domain-Specific Cultural Capital and Persistence in College." Social Science Research Published online first.}

test scores for $22 \%$, differences in the likelihood of attending a two- rather than four-year institution for $20 \%$, differences in first college selectivity for $7 \%$, and differences in advancing beyond Algebra II accounts for 7\% of this relationship. It is not surprising that youth's institutionalized cultural capital overshadows the contributions of their embodied cultural capital because the former represents explicit signals to both colleges and the young adult themselves as to their STEM potential. Because it is possible youth's institutionalized cultural capital is the result of their embodied cultural capital and other cultural capital building activities in the mechanism-causal-chain, we next use the top institutionalized STEM cultural capital and institutional characteristics mediators in these analyses as outcomes in the next set of analyses.

Table 5 shows results from decomposition analyses to examine which measures of adolescents' STEM-specific cultural capital building activities and STEM-specific embodied cultural capital mediate the relationship between their parents' STEM-specific educational cultural capital and adolescents' STEM-specific institutionalized cultural capital. All the potential mediators relate positively to all the achievement outcomes. Across the four achievement outcomes, the mediators that contribute the most are quite consistent, all accounting for between $1 \%$ and 3\% of most relationships. Differences in math self-efficacy/identity appears to be the most salient factor, explaining $9-10 \%$ of the relationship across all achievement outcomes. Recall that Table 3 showed that youth whose parent(s) have a STEM bachelor's degree have higher math self-efficacy/identity than youth whose parents have less STEMspecific educational cultural capital. Math utility value, in an exception, does not seem to be a factor in the intergenerational transmission of STEM-specific cultural capital. Table 6 shows results from decomposition analyses to examine which measures of adolescents' STEM-specific cultural capital building activities and STEM-specific embodied cultural capital mediate the

20 (2021. This manuscript version is made available under the CC-BY-NC-ND 4.0 license https://creativecommons.org/licenses/by-nc-nd/4.0/ 


\section{Tilbrook, Ned, and Dara Shifrer. 2021. "Domain-Specific Cultural Capital and Persistence in College." Social Science Research Published online first.}

relationship between their parents' STEM-specific educational cultural capital and the characteristics of the colleges youth attend. Although differences in math self-efficacy/identity contribute slightly less to these relationships, the patterns are generally the same. In sum, we find that parents with STEM degrees cultivate STEM-positive attitudes and interests in their children. These positive attitudes and interests then help children receive better grades, take more advanced classes, and attend more selective colleges, which in turn increase the likelihood that they study and persist in STEM at the college level.

\section{Discussion}

Our findings suggest that, within STEM, parents' field-specific cultural capital does indeed play a role in students majoring in and persisting in STEM majors, specifically in the form of parents' STEM education. That is, youth with parents with a bachelor's degree in STEM are not only more likely to intend and to persist in a STEM major than youth with parents with no bachelor's degree, but they are also significantly more likely to intend and persist in a STEM major than youth with parents with a bachelor's degree in some other field. Furthermore, it appears that this transmission of field-specific cultural capital is enacted through youths' fieldspecific embodied cultural capital (e.g., their STEM attitudes), field-specific institutionalized cultural capital (e.g., their STEM grades and test scores), and the characteristics of their educational institutions (e.g., attending a four-year rather than two-year college). Our analyses account for the dynamic nature of the transmission of field-specific cultural capital by examining how STEM-specific embodied cultural capital and cultural-capital building activities relate to institutional characteristics and STEM-specific institutionalized cultural capital, and how these ultimately relate to STEM major selection and persistence. This study builds on the previous research by not only identifying field-specific cultural capital but by explicitly documenting how

21 (2021. This manuscript version is made available under the CC-BY-NC-ND 4.0 license https://creativecommons.org/licenses/by-nc-nd/4.0/ 


\section{Tilbrook, Ned, and Dara Shifrer. 2021. "Domain-Specific Cultural Capital and Persistence in College." Social Science Research Published online first.}

parents transmit cultural capital to offspring through cultural-capital building activities, shaping attitudes, selecting educational institutions, and ultimately shaping achievement and college major outcomes. This study contributes to the theory of cultural capital by taking a nuanced perspective of the role of the social field in recognizing cultural resources as cultural capital.

\subsection{Field-Specific Cultural Capital}

Our hypothesis that cultural capital is field-specific is best supported by our finding that having a parent with a STEM bachelor's degree positively relates both to intending to major in STEM and to persisting in STEM majors, and that these positive effects appear larger not only relative to the estimated effect of not having a parent with a bachelor's degree, but also larger than the estimated positive effects of having a parent with a non-STEM bachelor's degree. STEM subjects are often particularly daunting (Turner et al. 2017), with STEM subjects perceived in the US as something that requires innate talent rather than hard work (Archer et al. 2010). The STEM field, relative to other fields, is also notably more exclusionary and less welcoming to persons who are women or racially/ethnically minoritized (Cech et al. 2011; Mann and DiPrete 2013; Morgan, Gelbgiser, and Weeden 2013; Riegle-Crumb and Grodsky 2010). This may explain why parents' STEM-specific cultural capital is particularly beneficial for both intending and persisting in a STEM major. These results may reflect differences in the overall highest level of education that respondents' parents obtain. It may be that those parents who have STEM degrees also have a higher proportion among them who hold advanced degrees within their fields. If this were the case, these parents would have had additional opportunities to build their own STEM-specific cultural capital, specifically within a university setting, that they could then subsequently pass on to their offspring.

22 (C2021. This manuscript version is made available under the CC-BY-NC-ND 4.0 license https://creativecommons.org/licenses/by-nc-nd/4.0/ 


\section{Tilbrook, Ned, and Dara Shifrer. 2021. "Domain-Specific Cultural Capital and Persistence in College." Social Science Research Published online first.}

Parents' occupations, on the other hand, do not appear to function as STEM-specific cultural capital in terms of STEM major intentions and persistence. Having a parent with a STEM education may be particularly useful for help in completing STEM coursework and navigating the university environment, while parents' occupational knowledge may be less relevant for their offspring's college experiences. This may also reflect a disconnect between the skills needed to obtain a degree in a STEM field and the skills needed to work in a STEM occupation (McGunagle and Zizka 2020); indeed while there is a shortage STEM skills in the private sector, the academic labor market is oversupplied (Xue and Larson 2015). If this were the case, we may then expect parental STEM occupation to hold a positive relationship with working in a STEM field after graduation. It is also possible that the effects of parental STEM education and occupation are compounding rather than additive, meaning that the effect of parental STEM occupation on STEM major selection and persistence is dependent upon parental STEM education.

\subsection{Intergenerational Transmission of Field-Specific Cultural Capital}

Our findings suggest that both institutionalized and embodied cultural capital are important mediators of the relationships between parents' STEM-specific educational cultural capital and youths' STEM major selection and persistence. These findings conform to prior research that shows high school course attainment, achievement, and institutional selectivity are important factors in choosing a college major (Allensworth, Nagaoka, and Johnson 2018; Engberg and Wolniak 2013; Long, Conger, and Iatarola 2012), but builds on this research by delineating a causal pathway for the transmission of cultural capital and then taking a fieldspecific lens. Consistent with Bordieu's view of educational institutions as central in the process of social reproduction, we find that youth's institutionalized cultural capital (i.e., their high

23 C2021. This manuscript version is made available under the CC-BY-NC-ND 4.0 license https://creativecommons.org/licenses/by-nc-nd/4.0/ 


\section{Tilbrook, Ned, and Dara Shifrer. 2021. "Domain-Specific Cultural Capital and Persistence in College." Social Science Research Published online first.}

school STEM grades and test scores) contribute the most to the positive relationship between having parents with a STEM degree and intending and persisting in a STEM major. As the primary selectors and sorters of who is deserving of a STEM major, it makes sense that educational institutions are most responsive to their own signals of merit and worth.

We also, find that math self-efficacy/identity is a key mediator between parents' education and both high school achievement and the characteristics of the college youth attend. This suggests that students take advanced high school STEM classes, receive better grades, and enroll in more selective institutions because the environment their parents create at home inculcates beliefs in the value of STEM, confidence in their own abilities in STEM, and piques further interest through the facilitation of STEM-related activities outside of the standard school curriculum. STEM-specific cultural capital building activities are small, but consistent contributors to high school achievement, suggesting that STEM-specific cultural capital building activities and STEM-specific embodied cultural capital play a role in how differences in parents' educational cultural capital relate to differences in the accumulation of STEM-specific institutionalized cultural capital. Illuminating a more subtle and intangible aspect of fieldspecific cultural capital, parents may create an environment at home which fosters the transmission of their STEM-specific embodied cultural capital to their offspring, which in turn allows youth to accumulate more STEM-specific institutionalized cultural capital and access educational institutions that promote their accumulation of more STEM-specific cultural capital.

\subsection{Implications}

Our findings support the idea that cultural capital can be specified as field-specific variants and that field-specific cultural capital is transmitted intergenerationally. We find that parents transmit their field-specific cultural capital by shaping youth's attitudes, beliefs, and

24 O2021. This manuscript version is made available under the CC-BY-NC-ND 4.0 license https://creativecommons.org/licenses/by-nc-nd/4.0/ 


\section{Tilbrook, Ned, and Dara Shifrer. 2021. "Domain-Specific Cultural Capital and Persistence in College." Social Science Research Published online first.}

activities. At home, parents emphasize the cultural resources that are recognized in the social fields they value or the fields in which they have personal experience. These ingrained attitudes, beliefs and participation then appear to be recognized as cultural capital by the teachers that act as gatekeepers in educational institutions, which allows for the accumulation of institutionalized cultural capital within that field for the child. The evidence we find for field-specific cultural capital joins a growing body of literature that focuses on specific social fields and seeks to understand how cultural resources are used and recognized as cultural capital within those fields (Laanan et al. 2010; Lareau et al. 2016; Starobin et al. 2016). We further contribute to this literature by examining the transmission of cultural capital within a specific educational field over a significant temporal trajectory, and by elucidating the multiple mechanisms through which this capital is transmitted and accrued. In conceptualizing the roles and mechanisms of field, embodied cultural capital, and institutionalized cultural capital, we honor Bourdieu's original ideas while also drawing on the scholarly work that has since critiqued and clarified his concepts (Bourdieu 1977, 1984, 1986; Farkas 2003, 2018; Kingston 2001; Lareau 2011; Lareau and Weininger 2003). Future research should focus on cultural capital in other social fields, or on further elucidating the dynamic mechanisms through which embodied and institutionalized cultural capital accumulate over time. Though we have mediators from several different time points, this is not a process that can be easily or discretely measured. Qualitative work on how attitudes shape achievement, and achievement in turn shapes attitudes, in specific field contexts may shed light on these mechanisms and how they differ across social fields.

\subsection{Limitations}

Some limitations merit mention. First, associations may reflect the influence of unmeasured or spurious factors, such that we are unable to infer causality in the associations we

25 C2021. This manuscript version is made available under the CC-BY-NC-ND 4.0 license https://creativecommons.org/licenses/by-nc-nd/4.0/ 


\section{Tilbrook, Ned, and Dara Shifrer. 2021. "Domain-Specific Cultural Capital and Persistence in College." Social Science Research Published online first.}

report. Relationships that are statistically significant using our definition of STEM may be driven by a smaller subsection of STEM fields in which field-specific cultural capital is vitally important, without field-specific cultural capital being important in other STEM fields. Previous research has found that disparities in STEM fields start earlier than high school (Morgan et al. 2016), potentially meaning that, through this data, we are witnessing a later manifestation of field-specific cultural capital that actually started much earlier. Also, as the latest wave of data collection occurred only three years after the end of high school for most respondents, the majority of respondents have not finished their degrees. Therefore, we are unable to know whether students persist with a STEM degree to graduation. Furthermore, some variables contain a high number of missing responses. The income variable contained the highest percentage of missing values at $34 \%$; in order to mitigate this, we include a categorical measure of income (on which only $22 \%$ of cases are missing) in multiple imputation models. Finally, some variables may lack validity due to being based on self-reports or due to social desirability bias.

\section{References}

Allensworth, Elaine M., Jenny Nagaoka, and David W. Johnson. 2018. High School Graduation and College Readiness Indicator Systems: What We Know, What We Need to Know. Chicago, IL: University of Chicago Consortium on School Research.

Andersen, Lori, and Thomas J. Ward. 2014. "Expectancy-Value Models for the STEM Persistence Plans of Ninth-Grade, High-Ability Students: A Comparison Between Black, Hispanic, and White Students." Science Education 98(2):216-42. doi: $10.1002 /$ sce. 21092

Archer, Louise, Jennifer DeWitt, Jonathan Osborne, Justin Dillon, Beatrice Willis, and Billy Wong. 2010. "'Doing' Science versus 'Being' a Scientist: Examining 10/11-Year-Old Schoolchildren's Constructions of Science through the Lens of Identity." Science Education 94(4):617-39. license https://creativecommons.org/licenses/by-nc-nd/4.0/ 
Tilbrook, Ned, and Dara Shifrer. 2021. "Domain-Specific Cultural Capital and Persistence in College." Social Science Research Published online first.

Bourdieu, Pierre. 1977. Outline of a Theory of Practice. Reprint edition. Cambridge: Cambridge University Press.

Bourdieu, Pierre. 1984. Distinction: A Social Critique of the Judgement of Taste. Cambridge, Mass: Harvard University Press.

Bourdieu, Pierre. 1986. "The Forms of Capital.” Pp. 241-58 in Handbook of Theorv and Research for the Sociology of Education, edited by J. G. Richardson. New York, NY: Greenwood Press.

Bulunuz, N., M. Bulunuz, and H. Peker. 2014. "Effects Of Formative Assessment Probes Integrated In Extra-Curricular Hands-On Science: Middle School Students' Understanding." Journal of Baltic Science Education 13(2):243-.

Carbonaro, William, and Elizabeth Covay. 2010. "School Sector and Student Achievement in the Era of Standards Based Reforms.” Sociology of Education 83(2):160-82.

Cech, Erin, Brian Rubineau, Susan Silbey, and Carroll Seron. 2011. "Professional Role Confidence and Gendered Persistence in Engineering." American Sociological Review 76(5):641-66.

Chen, Xianglei, and Matthew Soldner. 2013. STEM Attrition: College Students' Paths Into and Out of STEM Fields. NCES 2014-001. National Center for Education Statistics.

Cookson, Peter W., and Caroline H. Persell. 1985. Preparing for Power: America's Elite Boarding Schools. New York, NY: Basic Books.

Davies, Scott, and Jessica Rizk. 2018. "The Three Generations of Cultural Capital Research: A Narrative Review." Review of Educational Research 88(3):331-65. doi:

10.3102/0034654317748423.

DiMaggio, Paul. 1982. "Cultural Capital and School Success: The Impact of Status Culture Participation on the Grades of U.S. High School Students." American Sociological Review 47(2):189-201. doi: 10.2307/2094962.

DiMaggio, Paul, and John Mohr. 1985. "Cultural Capital, Educational Attainment, and Marital Selection.” American Journal of Sociology 90(6):1231-61.

Duprey, Michael A., Daniel J. Pratt, Donna M. Jewell, Melissa B. Cominole, Laura Burns Fritch, Ethan A. Ritchie, James E. Rogers, Jamie D. Wescott, and David H. Wilson. 2018. High School Longitudinal Study of 2009 (HSLS:09) Base-Year to Second Follow-Up Data File Documentation (NCES 2018-140). Washington, DC: National Center for Education Statistics, Institute of Education Sciences, U.S. Department of Education.

Engberg, Mark E., and Gregory C. Wolniak. 2013. "College Student Pathways to the STEM Disciplines." Teachers College Record 115(1):27.

27 (C2021. This manuscript version is made available under the CC-BY-NC-ND 4.0 license https://creativecommons.org/licenses/by-nc-nd/4.0/ 
Tilbrook, Ned, and Dara Shifrer. 2021. "Domain-Specific Cultural Capital and Persistence in College." Social Science Research Published online first.

Farkas, George. 2003. "Cognitive Skills and Noncognitive Traits and Behaviors in Stratification Processes." Annual Review of Sociology 29(1):541-62. doi:

10.1146/annurev.soc.29.010202.100023.

Farkas, George. 2018. "Family, Schooling, and Cultural Capital." Pp. 3-38 in Handbook of the Sociology of Education in the 21st Century, Handbooks of Sociology and Social Research, edited by B. Schneider. Cham: Springer International Publishing.

Gayo, Modesto. 2016. "Cultural Capital Reproduction in the UK."

Gonzalez, Heather B., and Jeffrey J. Kuenzi. 2012. Science, Technology, Engineering, and Mathematics (Stem) Education: A Primer. Washington, DC: Congressional Research Service.

Griffith, Amanda L. 2010. "Persistence of Women and Minorities in STEM Field Majors: Is It the School That Matters?" Economics of Education Review 29(6):911-22. doi: 10.1016/j.econedurev.2010.06.010.

Healy, Kieran, and James Moody. 2014. "Data Visualization in Sociology." Annual Review of Sociology 40(1):105-28. doi: 10.1146/annurev-soc-071312-145551.

Hedgecock, Sarah. 2016. "Is Nursing A STEM Field? Even Experts Disagree.” Forbes, March 29.

Hoffer, Thomas, Andrew M. Greeley, and James S. Coleman. 1985. "Achievement Growth in Public and Catholic Schools." Sociology of Education 58(2):74-97.

Holmes, Kathryn, Jennifer Gore, Max Smith, and Adam Lloyd. 2018. "An Integrated Analysis of School Students' Aspirations for STEM Careers: Which Student and School Factors Are Most Predictive?" International Journal of Science and Mathematics Education 16(4):655-75. doi: 10.1007/s10763-016-9793-z.

Jaeger, Mads Meier. 2011. "Does Cultural Capital Really Affect Academic Achievement? New Evidence from Combined Sibling and Panel Data." Sociology of Education 84(4):281-98.

Kingston, Paul W. 2001. "The Unfulfilled Promise of Cultural Capital Theory." Sociology of Education 74:88-99. doi: 10.2307/2673255.

Kohler, Ulrich, Kristian Bernt Karlson, and Anders Holm. 2011. "Comparing Coefficients of Nested Nonlinear Probability Models." Stata Journal 11(3):420-38.

Laanan, Frankie Santos, Soko S. Starobin, and Latrice E. Eggleston. 2010. "Adjustment of Community College Students at a Four-Year University: Role and Relevance of Transfer Student Capital for Student Retention." Journal of College Student Retention: Research, Theory \& Practice 12(2):175-209. doi: 10.2190/CS.12.2.d. license https://creativecommons.org/licenses/by-nc-nd/4.0/ 
Tilbrook, Ned, and Dara Shifrer. 2021. "Domain-Specific Cultural Capital and Persistence in College." Social Science Research Published online first.

Lamont, Michele, and Annette Lareau. 1988. "Cultural Capital: Allusions, Gaps and Glissandos in Recent Theoretical Developments." Sociological Theory 6(2):153-68. doi: $10.2307 / 202113$.

Lareau, Annette. 2003. Unequal Childhoods: Class, Race, and Family Life. Berkeley, CA: University of California Press.

Lareau, Annette. 2011. Unequal Childhoods: Class, Race, and Family Life, 2nd Edition with an Update a Decade Later. Second Edition, With an Update a Decade Later. Berkeley: University of California Press.

Lareau, Annette, Shani Adia Evans, and April Yee. 2016. "The Rules of the Game and the Uncertain Transmission of Advantage.” Sociology of Education 89(4):279-99.

Lareau, Annette, and Elliot B. Weininger. 2003. "Cultural Capital in Educational Research: A Critical Assessment." Theory and Society 32(5):567-606. doi: 10.1023/B:RYSO.0000004951.04408.b0.

Long, Mark C., Dylan Conger, and Patrice Iatarola. 2012. "Effects of High School CourseTaking on Secondary and Postsecondary Success." American Educational Research Journal 49(2):285-322.

Lubienski, Christopher A., and Sarah Theule Lubienski. 2013. The Public School Advantage: Why Public Schools Outperform Private Schools. Chicago, IL: University of Chicago Press.

Lubienski, Christopher, Corinna Crane, and Sarah Theule Lubienski. 2008. "What Do We Know about School Effectiveness? Academic Gains in Public and Private Schools." Phi Delta Kappan 89(9):689-95.

Mann, Allison, and Thomas A. DiPrete. 2013. "Trends in Gender Segregation in the Choice of Science and Engineering Majors." Social Science Research 42(6):1519-41. doi: 10.1016/j.ssresearch.2013.07.002.

Mazza, Gina L., Craig K. Enders, and Linda S. Ruehlman. 2015. “Addressing Item-Level Missing Data: A Comparison of Proration and Full Information Maximum Likelihood Estimation." Multivariate Behavioral Research 50(5):504-19.

McGunagle, Doreen, and Laura Zizka. 2020. "Employability Skills for 21st-Century STEM Students: The Employers' Perspective." Higher Education, Skills and Work-Based Learning 10(3):591-606. doi: 10.1108/HESWBL-10-2019-0148.

Moakler, Martin W., and Mikyong Minsun Kim. 2014. "College Major Choice in STEM: Revisiting Confidence and Demographic Factors." The Career Development Quarterly 62(2):128-42. doi: 10.1002/j.2161-0045.2014.00075.x. license https://creativecommons.org/licenses/by-nc-nd/4.0/ 
Tilbrook, Ned, and Dara Shifrer. 2021. "Domain-Specific Cultural Capital and Persistence in College." Social Science Research Published online first.

Morgan, Paul L., George Farkas, Marianne M. Hillemeier, and Steve Maczuga. 2016. "Science Achievement Gaps Begin Very Early, Persist, and Are Largely Explained by Modifiable Factors.” Educational Researcher 45(1):18-35. doi: 10.3102/0013189X16633182.

Morgan, Stephen L., Dafna Gelbgiser, and Kim A. Weeden. 2013. "Feeding the Pipeline: Gender, Occupational Plans, and College Major Selection." Social Science Research 42(4):989-1005. doi: 10.1016/j.ssresearch.2013.03.008.

Morgan, Stephen L., and Jennifer J. Todd. 2009. "Intergenerational Closure and Academic Achievement in High School: A New Evaluation of Coleman's Conjecture.” Sociology of Education 82:267-86.

Morris, David S. 2016. "Extracurricular Activity Participation in High School: Mechanisms Linking Participation to Math Achievement and 4-Year College Attendance." American Educational Research Journal 53(5):1376-1410. doi: 10.3102/0002831216667579.

Pianta, Robert C., and Arya Ansari. 2018. "Does Attendance in Private Schools Predict Student Outcomes at Age 15? Evidence From a Longitudinal Study." Educational Researcher 47(7):419-34. doi: 10.3102/0013189X18785632.

Riegle-Crumb, Catherine, and Eric Grodsky. 2010. "Racial-Ethnic Differences at the Intersection of Math Course-Taking and Achievement." Sociology of Education 83(3):248-70. doi: 10.1177/0038040710375689.

Riegle-Crumb, Catherine, Barbara King, and Yasmiyn Irizarry. 2019. "Does STEM Stand Out? Examining Racial/Ethnic Gaps in Persistence Across Postsecondary Fields." Educational Researcher 48(3):133-44. doi: 10.3102/0013189X19831006.

Riegle-Crumb, Catherine, Barbara King, and Chelsea Moore. 2016. "Do They Stay or Do They Go? The Switching Decisions of Individuals Who Enter Gender Atypical College Majors.” Sex Roles 74(9):436-49. doi: 10.1007/s11199-016-0583-4.

Rozek, Christopher S., Ryan C. Svoboda, Judith M. Harackiewicz, Chris S. Hulleman, and Janet S. Hyde. 2017. "Utility-Value Intervention with Parents Increases Students' STEM Preparation and Career Pursuit." Proceedings of the National Academy of Sciences 201607386. doi: 10.1073/pnas.1607386114.

Saw, Guan, Chi-Ning Chang, and Hsun-Yu Chan. 2018. "Cross-Sectional and Longitudinal Disparities in STEM Career Aspirations at the Intersection of Gender, Race/Ethnicity, and Socioeconomic Status." Educational Researcher 47(8):525-31. doi: 10.3102/0013189X18787818.

Schneider, Barbara, Michael Broda, Justina Judy, and Kri Burkander. 2013. "Pathways to College and STEM Careers: Enhancing the High School Experience.” New Directions for Youth Development 2013(140):9-29. doi: 10.1002/yd.20076. license https://creativecommons.org/licenses/by-nc-nd/4.0/ 
Tilbrook, Ned, and Dara Shifrer. 2021. "Domain-Specific Cultural Capital and Persistence in College." Social Science Research Published online first.

Shoffner, Marie F., Debbie Newsome, Casey A. Barrio Minton, and Carrie A. Wachter Morris. 2015. "A Qualitative Exploration of the STEM Career-Related Outcome Expectations of Young Adolescents.” Journal of Career Development 42(2):102-16. doi: 10.1177/0894845314544033.

Starobin, Soko S., Dimitra Jackson Smith, and Frankie Santos Laanan. 2016. "Deconstructing the Transfer Student Capital: Intersect between Cultural and Social Capital among Female Transfer Students in STEM Fields." Community College Journal of Research and Practice 40(12):1040-57. doi: 10.1080/10668926.2016.1204964.

Stephens, Nicole M., Tiffany N. Brannon, Hazel Rose Markus, and Jessica E. Nelson. 2015. "Feeling at Home in College: Fortifying School-Relevant Selves to Reduce Social Class Disparities in Higher Education." Social Issues and Policy Review 9(1):1-24. doi: 10.1111/sipr.12008.

Stolle-McAllister, Kathleen. 2011. "The Case for Summer Bridge: Building Social and Cultural Capital for Talented Black STEM Students.” Science Educator 20(2):12-22.

Sullivan, Alice. 2001. "Cultural Capital and Educational Attainment.” Sociology 35:893-912. doi: $10.1017 /$ S0038038501008938.

Turner, Sherri, Ju Joeng, Marcuetta Sims, Shari Dade, and Monica Froman Reid. 2017. "SES, Gender, and STEM Career Interests, Goals, and Actions: A Test of SCCT.” Journal of Career Assessment 1-17. doi: 10.1177/1069072717748665.

Wang, Xueli. 2013. "Why Students Choose STEM Majors: Motivation, High School Learning, and Postsecondary Context of Support." American Educational Research Journal 50(5):1081-1121. doi: 10.3102/0002831213488622.

White, Ian R., Patrick Royston, and Angela M. Wood. 2011. "Multiple Imputation Using Chained Equations: Issues and Guidance for Practice." Statistics in Medicine 30(4):37799. doi: 10.1002/sim.4067.

Xue, Yi, and Richard C. Larson. 2015. "STEM Crisis or STEM Surplus? Yes and Yes." Monthly Labor Review 2015:10.21916/mlr.2015.14.

Yee, April. 2016. “The Unwritten Rules Of Engagement: Social Class Differences in Undergraduates' Academic Strategies.” The Journal of Higher Education 87(6):831-58. doi: 10.1353/jhe.2016.0031.

Zavrel, Erik A. 2011. "How the Discovery Channel Television Show 'Mythbusters' Accurately Depicts Science and Engineering Culture." Journal of Science Education and Technology 20(2):201-7. doi: http://dx.doi.org/10.1007/s10956-010-9246-3.

31 C2021. This manuscript version is made available under the CC-BY-NC-ND 4.0 license https://creativecommons.org/licenses/by-nc-nd/4.0/ 
Tilbrook, Ned, and Dara Shifrer. 2021. "Domain-Specific Cultural Capital and Persistence in College." Social Science Research Published online first.

\section{Appendix A: Survey Items Used to Construct STEM Attitude Scales}

Math Identity and Self-Efficacy (alpha=0.78)

Others see as math person

Sees self as math person

Taking math because does well in it

Taking math because enjoys it

Math Utility Value (relates well to goals) (alpha=0.78)

Thinks math is useful for college

Thinks math is useful for career

Thinks math is useful for everyday life

Science Identity and Self-Efficacy (alpha=0.77)

Taking science because enjoys it

Taking science because likes challenge

Taking science $\mathrm{b} / \mathrm{c}$ does well in it

Taking science to succeed in college

Sees self as science person

Others see as science person

Science Utility Value (relates well to goals) $($ alpha $=0.82)$

Thinks science is useful for college

Thinks science is useful for career

Thinks science is useful for everyday life

32 (C2021. This manuscript version is made available under the CC-BY-NC-ND 4.0 license https://creativecommons.org/licenses/by-nc-nd/4.0/ 
Tilbrook, Ned, and Dara Shifrer. 2021. "Domain-Specific Cultural Capital and Persistence in College." Social Science Research Published online first.

Table 1, part 1 of 2: Descriptive Statistics by Analytic Sample

\begin{tabular}{|c|c|c|c|c|}
\hline & \multicolumn{2}{|c|}{$\begin{array}{l}\text { Intending College } \\
\text { Analytic Sample } \\
(n=12,730)\end{array}$} & \multicolumn{2}{|c|}{$\begin{array}{l}\text { Intended STEM } \\
\text { Major Analytic } \\
\text { Sample }(n=3,250)\end{array}$} \\
\hline & $\begin{array}{c}\text { Mean/ } \\
\text { proportion }\end{array}$ & $(S D)$ & $\begin{array}{c}\text { Mean/ } \\
\text { proportion }\end{array}$ & (SD) \\
\hline \multicolumn{5}{|c|}{ DEPENDENT VARIABLES: STEM Major Intentions and Persistence } \\
\hline Intended STEM major (W3) & 0.28 & & & \\
\hline Persisted with STEM major (W4) & & & 0.64 & \\
\hline \multicolumn{5}{|c|}{ PREDICTORS OF INTEREST: Parents' STEM-Specific Cultural Capital } \\
\hline Parent(s)' occupation is in STEM (W1) & 0.12 & & 0.15 & \\
\hline \multicolumn{5}{|l|}{ Parents' educational attainment (W1): } \\
\hline No parent has bachelor's & 0.55 & & 0.47 & \\
\hline Parent(s) has a bachelor's, but not in STEM & 0.27 & & 0.29 & \\
\hline Parent(s) has bachelor's in STEM & 0.18 & & 0.24 & \\
\hline \multicolumn{5}{|c|}{ MEDIATORS: Adolescent's STEM-Specific Cultural Capital Building Activities } \\
\hline Visited science/engineering museum with parents (W1) & 0.56 & & 0.58 & \\
\hline Discussed STEM documentary/article with parents (W1) & 0.68 & & 0.72 & \\
\hline Participated in math extra-curricular activities (W1) & 0.11 & & 0.14 & \\
\hline Participated in science extra-curricular activities (W1) & 0.08 & & 0.11 & \\
\hline \multicolumn{5}{|c|}{ MEDIATORS: Adolescent's STEM-Specific Embodied Cultural Capital } \\
\hline Math self-efficacy/identity (W2) & 0.09 & $(0.02)$ & 0.41 & $(0.04)$ \\
\hline Science self-efficacy/identity (W2) & 0.05 & $(0.02)$ & 0.28 & $(0.03)$ \\
\hline Math utility value (W2) & 0.07 & $(0.02)$ & 0.24 & $(0.03)$ \\
\hline Science utility value (W2) & 0.04 & $(0.02)$ & 0.34 & $(0.03)$ \\
\hline Expects STEM occupation at age 30 (W2) & 0.13 & & 0.31 & \\
\hline Chose 2016 major because did well in that major's cours & ses (W4) & & 0.79 & \\
\hline Chose 2016 major because was encouraged to choose it & $t(W 4)$ & & 0.47 & \\
\hline \multicolumn{5}{|c|}{ MEDIATORS: Adolescent's STEM-Specific Insitutionalized Cultural Capital } \\
\hline Advanced beyond algebra II (transcript) & 0.49 & & 0.65 & \\
\hline Earned high school physics credit (transcript) & 0.42 & & 0.57 & \\
\hline High school STEM grade point average (transcript) & 2.68 & $(0.02)$ & 2.94 & $(0.03)$ \\
\hline Math test score (W2) & 0.21 & $(0.03)$ & 0.65 & $(0.04)$ \\
\hline
\end{tabular}

33 C2021. This manuscript version is made available under the CC-BY-NC-ND 4.0 license https://creativecommons.org/licenses/by-nc-nd/4.0/ 
Tilbrook, Ned, and Dara Shifrer. 2021. "Domain-Specific Cultural Capital and Persistence in College." Social Science Research Published online first.

Table 1, part 2 of 2: Descriptive Statistics by Analytic Sample

\begin{tabular}{|c|c|c|c|c|}
\hline & \multicolumn{2}{|c|}{$\begin{array}{l}\text { Intending College } \\
\text { Analytic Sample } \\
(n=12,730)\end{array}$} & \multicolumn{2}{|c|}{$\begin{array}{l}\text { Intended STEM } \\
\text { Major Analytic } \\
\text { Sample }(n=3,250)\end{array}$} \\
\hline & $\begin{array}{c}\text { Mean/ } \\
\text { proportion }\end{array}$ & (SD) & $\begin{array}{c}\text { Mean/ } \\
\text { proportion }\end{array}$ & (SD) \\
\hline \multicolumn{5}{|l|}{ MEDIATORS: Characteristics of Institutions } \\
\hline \multicolumn{5}{|l|}{ High school sector (W1): } \\
\hline Public & 0.90 & & 0.89 & \\
\hline Catholic & 0.05 & & 0.06 & \\
\hline Non-Catholic private & 0.05 & & 0.05 & \\
\hline First college is non-four year institution (W4) & & & 0.24 & \\
\hline \multicolumn{5}{|l|}{ Sector of first college (W4): } \\
\hline Public & & & 0.77 & \\
\hline Private, non-profit & & & 0.21 & \\
\hline Private, for-profit & & & 0.02 & \\
\hline \multicolumn{5}{|l|}{ Selectivity of first college (W4): } \\
\hline Non-selective & & & 0.37 & \\
\hline Medium selectivity & & & 0.30 & \\
\hline High selectivity & & & 0.33 & \\
\hline \multicolumn{5}{|l|}{ Controls } \\
\hline \multicolumn{5}{|l|}{ Race (W1): } \\
\hline White & 0.55 & & 0.58 & \\
\hline Black & 0.12 & & 0.08 & \\
\hline Latinx & 0.20 & & 0.19 & \\
\hline Asian & 0.05 & & 0.07 & \\
\hline Other & 0.08 & & 0.08 & \\
\hline Female (W1) & 0.52 & & 0.38 & \\
\hline Household income (W1, in units of $\$ 10,000)$ & 9.21 & $(0.28)$ & 10.09 & $(0.36)$ \\
\hline
\end{tabular}

34 C2021. This manuscript version is made available under the CC-BY-NC-ND 4.0 license https://creativecommons.org/licenses/by-nc-nd/4.0/ 
Tilbrook, Ned, and Dara Shifrer. 2021. "Domain-Specific Cultural Capital and Persistence in College." Social Science Research Published online first.

Table 2: Odds Ratios from Logistic Regression Models Predicting Intending and Persisting in College STEM Majors

\begin{tabular}{|c|c|c|c|c|c|c|}
\hline & \multicolumn{3}{|c|}{$\begin{array}{c}\text { Model } 1 \\
\text { Major Intention } \\
(n=12,730)\end{array}$} & \multicolumn{3}{|c|}{$\begin{array}{c}\text { Model } 2 \\
\text { Major Persistence } \\
(n=3,250)\end{array}$} \\
\hline & $\operatorname{Exp}(B)$ & & (SE) & $\operatorname{Exp}(B)$ & & $(\mathrm{SE})$ \\
\hline \multicolumn{7}{|l|}{ Parents' STEM-Specific Cultural Capital } \\
\hline Parent(s)' occupation is in STEM (W1) & 1.18 & & $(0.11)$ & 1.18 & & $(0.22)$ \\
\hline \multicolumn{7}{|l|}{ Parents' educational attainment (W1): } \\
\hline No parent has bachelor's & - & & & - & & \\
\hline Parent(s) has a bachelor's, but not in STEM & 1.37 & $* * *$ & $(0.12)$ & 1.41 & $*$ & $(0.21)$ \\
\hline Parent(s) has bachelor's in STEM & 1.79 & $* * *$ & $(0.17)$ & 2.06 & $* * *$ & $(0.37)$ \\
\hline \multicolumn{7}{|l|}{ Controls } \\
\hline \multicolumn{7}{|l|}{ Race (W1): } \\
\hline White & - & & & - & & \\
\hline Black & 0.64 & $* *$ & (0.09) & 0.50 & $* *$ & $(0.13)$ \\
\hline Latinx & 1.07 & & $(0.14)$ & 0.60 & & $(0.16)$ \\
\hline Asian & 1.67 & $* * *$ & $(0.23)$ & 1.17 & & $(0.28)$ \\
\hline Other & 0.97 & & $(0.12)$ & 0.62 & $*$ & $(0.13)$ \\
\hline Female (W1) & 0.46 & $* * *$ & $(0.04)$ & 1.23 & & (0.19) \\
\hline Household income (W1, in units of $\$ 10,000)$ & 1.00 & & $(0.00)$ & 1.01 & & $(0.01)$ \\
\hline
\end{tabular}

Note: Model 1 uses the Intending College Analytic Sample and Model 2 uses the Intended STEM Major Analytic Sample.

$* * * p<0.001, * * p<0.01, * p<0.05$

35 C2021. This manuscript version is made available under the CC-BY-NC-ND 4.0 license https://creativecommons.org/licenses/by-nc-nd/4.0/ 
Tilbrook, Ned, and Dara Shifrer. 2021. "Domain-Specific Cultural Capital and Persistence in College." Social Science Research Published online first.

Table 3, Part 1 of 2: Bivariate Differences by Parents' STEM-Specific Education in Potential Mediators $(n=12,730)$

\begin{tabular}{|c|c|c|c|c|c|c|}
\hline & \multicolumn{3}{|c|}{$\begin{array}{c}\text { Parents' bachelor } \\
\text { degree status }\end{array}$} & \multicolumn{3}{|c|}{$\begin{array}{c}\text { Statistical significance } \\
\text { estimates } \\
\end{array}$} \\
\hline & & Not & & Not STEM & STEM vs. & STEM vs. \\
\hline & None & STEM & STEM & vs. None & None & Not STEM \\
\hline \multicolumn{7}{|l|}{ Adolescent's STEM-Specific Cultural Capital Building Activities } \\
\hline Visited science/engineering museum with parents (W1) & 0.49 & 0.62 & 0.67 & $* * *$ & $* * *$ & $* *$ \\
\hline Discussed STEM documentary/article with parents (W1) & 0.62 & 0.73 & 0.78 & $* *$ & $* * *$ & $* *$ \\
\hline Participated in math extra-curricular activities (W1) & 0.10 & 0.12 & 0.15 & & $* * *$ & $* *$ \\
\hline Participated in science extra-curricular activities (W1) & 0.06 & 0.08 & 0.13 & $* *$ & $* * *$ & $* * *$ \\
\hline \multicolumn{7}{|l|}{ Adolescent's STEM-Specific Embodied Cultural Capital } \\
\hline Math self-efficacy/identity (W2) & 0.02 & 0.13 & 0.27 & $* *$ & $* * *$ & $* *$ \\
\hline Science self-efficacy/identity (W2) & 0.00 & 0.11 & 0.12 & $* *$ & $* *$ & $* *$ \\
\hline Math utility value (W2) & 0.09 & 0.00 & 0.08 & $* *$ & & \\
\hline Science utility value (W2) & 0.00 & 0.06 & 0.15 & & $* * *$ & $* *$ \\
\hline Expects STEM occupation at age 30 (W2) & 0.12 & 0.13 & 0.18 & $* * *$ & $* * *$ & $* * *$ \\
\hline Chose 2016 major because did well in that major's courses (W4) & 0.78 & 0.81 & 0.82 & & $*$ & \\
\hline Chose 2016 major because was encouraged to choose it (W4) & 0.43 & 0.50 & 0.50 & $* * *$ & $* *$ & $* *$ \\
\hline \multicolumn{7}{|c|}{ MEDIATORS: Adolescent's STEM-Specific Insitutionalized Cultural Capital } \\
\hline Advanced beyond algebra II (transcript) & 0.39 & 0.57 & 0.71 & $* * *$ & $* * *$ & $* * *$ \\
\hline Earned high school physics credit (transcript) & 0.35 & 0.46 & 0.57 & $* * *$ & $* * *$ & $* * *$ \\
\hline High school STEM grade point average (transcript) & 2.48 & 2.86 & 3.04 & $* * *$ & $* * *$ & $* * *$ \\
\hline Math test score (W2) & -0.06 & 0.41 & 0.74 & $* * *$ & $* * *$ & $* * *$ \\
\hline
\end{tabular}


Tilbrook, Ned, and Dara Shifrer. 2021. "Domain-Specific Cultural Capital and Persistence in College." Social Science Research Published online first.

Table 3, Part 2 of 2: Bivariate Differences by Parents' STEM-Specific Education in Potential Mediators $(n=12,730)$

\begin{tabular}{|c|c|c|c|c|c|c|}
\hline & \multicolumn{3}{|c|}{$\begin{array}{c}\text { Parents' bachelor } \\
\text { degree status }\end{array}$} & \multicolumn{3}{|c|}{$\begin{array}{c}\text { Statistical significance } \\
\text { estimates } \\
\end{array}$} \\
\hline & & Not & & Not STEM & STEM vs. & STEM vs. \\
\hline & None & STEM & STEM & vs. None & None & Not STEM \\
\hline \multicolumn{7}{|l|}{ Characteristics of Institutions } \\
\hline \multicolumn{7}{|l|}{ High school sector (W1): } \\
\hline Public & 0.96 & 0.84 & 0.83 & ref & ref & ref \\
\hline Catholic & 0.03 & 0.08 & 0.08 & $* * *$ & $* * *$ & \\
\hline Non-Catholic private & 0.02 & 0.08 & 0.09 & $* * *$ & $* * *$ & \\
\hline First college is non-four year institution (W4) & 0.49 & 0.27 & 0.17 & $* * *$ & $* * *$ & $* * *$ \\
\hline \multicolumn{7}{|l|}{ Sector of first college (W4): } \\
\hline Public & 0.81 & 0.75 & 0.72 & ref & ref & ref \\
\hline Private, non-profit & 0.13 & 0.22 & 0.28 & $* * *$ & $* * *$ & $* *$ \\
\hline Private, for-profit & 0.06 & 0.03 & 0.01 & $* * *$ & $* * *$ & $* *$ \\
\hline \multicolumn{7}{|l|}{ Selectivity of first college (W4): } \\
\hline Non-selective & 0.67 & 0.41 & 0.27 & ref & ref & ref \\
\hline Medium selectivity & 0.24 & 0.33 & 0.31 & $* * *$ & $* * *$ & $* *$ \\
\hline High selectivity & 0.09 & 0.26 & 0.41 & $* * *$ & $* * *$ & $* * *$ \\
\hline
\end{tabular}

Note: These analyses use the Intending College Analytic Sample. Exploratory analyses demonstrated results were similar to those relying on the Intending STEM Major analytic sample.

$* * * p<0.001, * * p<0.01, * p<0.05$ 
Tilbrook, Ned, and Dara Shifrer. 2021. "Domain-Specific Cultural Capital and Persistence in College." Social Science Research Published online first.

Table 4, Part 1 of 2: Mediators of the Relationship between Parents' STEM-Specific Education and Students' STEM

Major Outcomes

\begin{tabular}{|c|c|c|c|c|}
\hline & \multicolumn{2}{|c|}{$\begin{array}{c}\text { Model } 1 \\
\text { Intending STEM Major } \\
(n=12,730) \\
\end{array}$} & \multicolumn{2}{|c|}{$\begin{array}{c}\text { Model } 2 \\
\text { Persisted in STEM Major } \\
(n=3,250)\end{array}$} \\
\hline & $\begin{array}{c}\text { Mediator and } \\
\text { outcome }^{\mathrm{a}} \\
\end{array}$ & 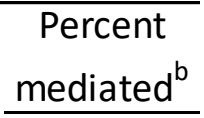 & $\begin{array}{c}\text { Mediator and } \\
\text { outcome }^{\mathrm{a}} \\
\end{array}$ & $\begin{array}{c}\text { Percent } \\
\text { mediated }^{\mathrm{b}} \\
\end{array}$ \\
\hline \multicolumn{5}{|c|}{ Adolescent's STEM-Specific Cultural Capital Building Activities } \\
\hline Visited science/engineering museum with parents (W1) & + & - & + & $3 \%$ \\
\hline Discussed STEM documentary/article with parents (W1) & + & $1 \%$ & + & - \\
\hline Participated in math extra-curricular activities (W1) & + & - & + & - \\
\hline Participated in science extra-curricular activities (W1) & + & $1 \%$ & + & - \\
\hline \multicolumn{5}{|l|}{ Adolescent's STEM-Specific Embodied Cultural Capital } \\
\hline Math self-efficacy/identity (W2) & + & $2 \%$ & + & - \\
\hline Science self-efficacy/identity (W2) & + & - & + & - \\
\hline Math utility value (W2) & + & - & + & - \\
\hline Science utility value (W2) & + & $4 \%$ & + & $1 \%$ \\
\hline Expects STEM occupation at age 30 (W2) & + & $11 \%$ & + & $1 \%$ \\
\hline Chose 2016 major because did well in that major's courses (W4) & NA & & + & $1 \%$ \\
\hline Chose 2016 major because was encouraged to choose it (W4) & NA & & + & - \\
\hline \multicolumn{5}{|c|}{ MEDIATORS: Adolescent's STEM-Specific Insitutionalized Cultural Capital } \\
\hline Advanced beyond algebra II (transcript) & + & $1 \%$ & + & $7 \%$ \\
\hline Earned high school physics credit (transcript) & + & $8 \%$ & + & $4 \%$ \\
\hline High school STEM grade point average (transcript) & + & $16 \%$ & + & $45 \%$ \\
\hline Math test score (W2) & + & $31 \%$ & + & $22 \%$ \\
\hline
\end{tabular}


Tilbrook, Ned, and Dara Shifrer. 2021. "Domain-Specific Cultural Capital and Persistence in College." Social Science Research Published online first.

Table 4, Part 2 of 2: Mediators of the Relationship between Parents' STEM-Specific Education and Students' STEM Major Outcomes

\begin{tabular}{|c|c|c|c|c|}
\hline \multirow[b]{3}{*}{ Characteristics of Institutions } & \multicolumn{2}{|c|}{$\begin{array}{c}\text { Model } 1 \\
\text { Intending STEM Major } \\
(n=12,730)\end{array}$} & \multicolumn{2}{|c|}{$\begin{array}{c}\text { Model } 2 \\
\text { Persisted in STEM Major } \\
(n=3,250)\end{array}$} \\
\hline & $\begin{array}{c}\text { Mediator and } \\
\text { outcome }^{\mathrm{a}} \\
\end{array}$ & $\begin{array}{c}\text { Percent } \\
\text { mediated }^{\mathrm{b}} \\
\end{array}$ & $\begin{array}{c}\text { Mediator and } \\
\text { outcome }^{\mathrm{a}} \\
\end{array}$ & $\begin{array}{c}\text { Percent } \\
\text { mediated }^{\mathrm{b}} \\
\end{array}$ \\
\hline & & & & \\
\hline High school sector (W1): & & - & & $1 \%$ \\
\hline Public & - & & - & \\
\hline Catholic & + & & + & \\
\hline Non-Catholic private & + & & + & \\
\hline First college is non-four year institution (W4) & NA & & - & $20 \%$ \\
\hline Sector of first college (W4): & NA & & & - \\
\hline Public & & & - & \\
\hline Private, non-profit & & & + & \\
\hline Private, for-profit & & & + & \\
\hline Selectivity of first college (W4): & NA & & & $7 \%$ \\
\hline Non-selective & & & - & \\
\hline Medium selectivity & & & + & \\
\hline High selectivity & & & + & \\
\hline
\end{tabular}

Note: Model 1 uses the Intending College Analytic Sample and Model 2 uses the Intended STEM Major Analytic Sample.

a-These columns show how the potential mediators relate to the outcome of interest, with + indicating a positive relationship and - indicating a negative relationship. NA indicates the measure does not make sense as a potential mediator because of temporal ordering.

b-These columns indicate the percent of the relationship between parents' STEM-specific education and respondents' STEM-major outcome explained by each potential mediator, after adjusting for the contributions of other potential mediators and control variables (students' race, students' gender, parents' occupations, and family income). A hyphen indicates the measure does not mediate the relationship.

$* * * p<0.001, * * p<0.01,{ }^{*} p<0.05$

39 C2021. This manuscript version is made available under the CC-BY-NC-ND 4.0 license https://creativecommons.org/licenses/by-nc$\underline{\mathrm{nd} / 4.0 /}$ 
Tilbrook, Ned, and Dara Shifrer. 2021. "Domain-Specific Cultural Capital and Persistence in College.” Social Science Research Published online first.

Table 5: Mediators of the Relationship between Parents' STEM-Specific Education and Adolescent's STEM-Specific Institutionalized Cultural Capital ( $\mathrm{n}=12,730$ )

\begin{tabular}{|c|c|c|c|c|c|c|c|c|}
\hline & \multicolumn{2}{|c|}{$\begin{array}{c}\text { Model } 1 \\
\text { Advanced beyond } \\
\text { algebra II (transcript) }\end{array}$} & \multicolumn{2}{|c|}{$\begin{array}{c}\text { Model } \mathbf{2} \\
\text { Earned high school } \\
\text { physics credit }\end{array}$} & \multicolumn{2}{|c|}{$\begin{array}{c}\text { Model } 3 \\
\text { Math test score (W2) }\end{array}$} & \multicolumn{2}{|c|}{$\begin{array}{c}\text { Model } 4 \\
\text { High school STEM GPA } \\
\text { (transcript) }\end{array}$} \\
\hline & $\begin{array}{c}\text { Mediator and } \\
\text { outcome }^{\mathrm{a}}\end{array}$ & $\begin{array}{c}\text { Percent } \\
\text { mediated }^{\mathrm{b}}\end{array}$ & $\begin{array}{c}\text { Mediator and } \\
\text { outcome }^{\mathrm{a}}\end{array}$ & $\begin{array}{c}\text { Percent } \\
\text { mediated }^{b}\end{array}$ & $\begin{array}{c}\text { Mediator and } \\
\text { outcome }^{\mathrm{a}}\end{array}$ & $\begin{array}{c}\text { Percent } \\
\text { mediated }^{\mathrm{b}}\end{array}$ & $\begin{array}{c}\text { Mediator and } \\
\text { outcome }^{a}\end{array}$ & $\begin{array}{c}\text { Percent } \\
\text { mediated }^{b}\end{array}$ \\
\hline \multicolumn{9}{|c|}{ Adolescent's STEM-Specific Cultural Capital Building Activities } \\
\hline Visited science/engineering museum with parents (W1 & + & $1 \%$ & + & $1 \%$ & + & $1 \%$ & + & $3 \%$ \\
\hline Discussed STEM documentary/article with parents (W1 & + & $1 \%$ & + & - & + & $1 \%$ & + & - \\
\hline Participated in math extra-curricular activities (W1) & + & $1 \%$ & + & $1 \%$ & + & $2 \%$ & + & $1 \%$ \\
\hline Participated in science extra-curricular activities (W1) & + & $1 \%$ & + & $2 \%$ & + & - & + & - \\
\hline \multicolumn{9}{|l|}{ Adolescent's STEM-Specific Embodied Cultural Capital } \\
\hline Math self-efficacy/identity (W2) & + & $9 \%$ & + & $9 \%$ & + & $9 \%$ & + & $10 \%$ \\
\hline Science self-efficacy/identity (W2) & + & $1 \%$ & + & - & + & $1 \%$ & + & $1 \%$ \\
\hline Math utility value (W2) & + & - & + & - & + & - & + & - \\
\hline Science utility value (W2) & + & $2 \%$ & + & $2 \%$ & + & $1 \%$ & + & $2 \%$ \\
\hline Expects STEM occupation at age 30 (W2) & + & $2 \%$ & + & $3 \%$ & + & $1 \%$ & + & $1 \%$ \\
\hline
\end{tabular}

Note: These analyses use the Intending College Analytic Sample.

a-These columns show how the potential mediators relate to the outcome of interest, with + indicating a positive relationship and - indicating a negative relationship. NA indicates the measure does not make sense as a potential mediator because of temporal ordering.

b-These columns indicate the percent of the relationship between parents' STEM-specific education and respondents' STEM-major outcome explained by each potential mediator, after adjusting for the contributions of other potential mediators and control variables (students' race, students' gender, parents' occupations, and family income). A hyphen indicates the measure does not mediate the relationship.

$* * * p<0.001, * * p<0.01, * p<0.05$ 
Tilbrook, Ned, and Dara Shifrer. 2021. "Domain-Specific Cultural Capital and Persistence in College." Social Science Research Published online first.

Table 6: Mediators of the Relationship between Parents' STEM-Specific Education and the Characteristics

of Respondents' Institutions ( $\mathrm{n}=12,730)$

\begin{tabular}{|c|c|c|c|c|}
\hline & \multicolumn{2}{|c|}{$\begin{array}{l}\text { Model } 1 \\
\text { First college is non-four } \\
\text { year institution (W4) }\end{array}$} & \multicolumn{2}{|c|}{$\begin{array}{c}\text { Model } 2 \\
\text { Selectivity of first college } \\
\text { (W4) }\end{array}$} \\
\hline & $\begin{array}{c}\text { Mediator and } \\
\text { outcome }^{\mathrm{a}} \\
\end{array}$ & $\begin{array}{c}\text { Percent } \\
\text { mediated }^{\text {b }}\end{array}$ & $\begin{array}{c}\text { Mediator and } \\
\text { outcome }^{a}\end{array}$ & $\begin{array}{c}\text { Percent } \\
\text { mediated }^{\mathrm{b}}\end{array}$ \\
\hline \multicolumn{5}{|c|}{ Adolescent's STEM-Specific Cultural Capital Building Activities } \\
\hline Visited science/engineering museum with parents (W1) & - & $2 \%$ & + & $1 \%$ \\
\hline Discussed STEM documentary/article with parents (W1) & - & $3 \%$ & + & $1 \%$ \\
\hline Participated in math extra-curricular activities (W1) & - & $2 \%$ & + & $1 \%$ \\
\hline Participated in science extra-curricular activities (W1) & & $1 \%$ & & $1 \%$ \\
\hline \multicolumn{5}{|l|}{ Adolescent's STEM-Specific Embodied Cultural Capital } \\
\hline Math self-efficacy/identity (W2) & - & $4 \%$ & + & $4 \%$ \\
\hline Science self-efficacy/identity (W2) & - & $1 \%$ & + & - \\
\hline Math utility value (W2) & - & - & + & - \\
\hline Science utility value (W2) & - & $1 \%$ & + & $1 \%$ \\
\hline Expects STEM occupation at age 30 (W2) & - & $1 \%$ & + & $1 \%$ \\
\hline
\end{tabular}

Note: These analyses use the Intending College Analytic Sample.

a-These columns show how the potential mediators relate to the outcome of interest, with + indicating a positive relationship and - indicating a negative relationship. NA indicates the measure does not make sense as a potential mediator because of temporal ordering.

b-These columns indicate the percent of the relationship between parents' STEM-specific education and respondents' STEM-major outcome explained by each potential mediator, after adjusting for the contributions of other potential mediators and control variables (students' race, students' gender, parents' occupations, and family income). A hyphen indicates the measure does not mediate the relationship.

$* * * p<0.001, * * p<0.01, * p<0.05$

41 C2021. This manuscript version is made available under the CC-BY-NC-ND 4.0 license https://creativecommons.org/licenses/by-nc$\underline{\mathrm{nd} / 4.0 /}$ 
Tilbrook, Ned, and Dara Shifrer. 2021. "Domain-Specific Cultural Capital and Persistence in College." Social Science Research Published online first.

Online Table 1, part 1 of 2: Descriptive Statistics, Social Sciences Sensitivity Anlyses

\begin{tabular}{cc}
$\begin{array}{c}\text { Intending College } \\
\text { Analytic Sample } \\
(n=12,730)\end{array}$ & $\begin{array}{c}\text { Intending Social } \\
\text { Sciences analytic } \\
\text { sample }(\mathrm{n}=630)\end{array}$ \\
\hline Mean/ & Mean/ \\
proportion (S.D.) & proportion (S.D.) \\
\hline
\end{tabular}

DEPENDENT VARIABLES: Social science Major Intentions and Persistence

Intends social sciences major (W3) 0.06

Persisted with social sciences major (W4) $\quad 0.62$

PREDICTORS OF INTEREST: Parents' field-Specific Cultural Capital

$\begin{array}{lll}\text { Parent(s) has a social sciences occupation } & 0.004 & 0.01\end{array}$

Parental education

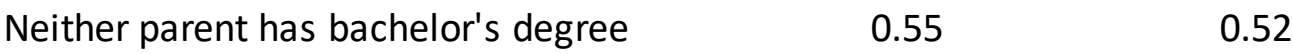

$\begin{array}{lll}\text { Parent(s) has a bachelor's, but not a } & 0.39 & 0.40\end{array}$

social sciences bachelor's

$\begin{array}{lll}\text { Parent(s) has a social sciences bachelor's } & 0.05 & 0.08\end{array}$

MEDIATORS: Adolescent's STEM-Specific Embodied Cultural Capital

$\begin{array}{lllll}\text { Math self-efficacy identity (W2) } & 0.09 & (0.02) & -0.16 & (0.07)\end{array}$

$\begin{array}{lllll}\text { Science self-efficacy identity (W2) } & 0.05 & (0.02) & -0.09 & (0.09)\end{array}$

$\begin{array}{lllll}\text { Math utility value (W2) } & 0.06 & (0.02) & -0.09 & (0.07)\end{array}$

$\begin{array}{lllll}\text { Science utility value (W2) } & 0.04 & (0.02) & -0.02 & (0.06)\end{array}$

Expects STEM occupation at age 30 (W2) $\quad 0.13 \quad 0.23$

Chose 2016 major beause (all W4):

Did well in that major's courses $\quad 0.80$

was encouraged to choose major $\quad 0.44$

MEDIATORS: Adolescent's STEM-Specific Insitutional Cultural Capital

$\begin{array}{lll}\text { Advanced beyond algebra II (W3 transcript) } & 0.50 & 0.50\end{array}$

$\begin{array}{lll}\text { Earned high school physics credit (W3 transcript) } & 0.42 & 0.41\end{array}$

$\begin{array}{lllll}\text { High school STEM GPA } & 2.68 & (0.02) & 2.71 & (0.06)\end{array}$

\begin{tabular}{lllll} 
Math test score (W2) & 0.21 & $(0.03)$ & 0.35 & $(0.09)$ \\
\hline
\end{tabular}

42 C2021. This manuscript version is made available under the CC-BY-NC-ND 4.0 license https://creativecommons.org/licenses/by-nc-nd/4.0/ 
Tilbrook, Ned, and Dara Shifrer. 2021. "Domain-Specific Cultural Capital and Persistence in College." Social Science Research Published online first.

Online Table 1, part 2 of 2: Descriptive Statistics, Social Sciences Sensitivity Anlyses

\begin{tabular}{|c|c|c|c|c|}
\hline & \multicolumn{2}{|c|}{$\begin{array}{c}\text { Intending College } \\
\text { Analytic Sample } \\
(n=12,730)\end{array}$} & \multicolumn{2}{|c|}{$\begin{array}{l}\text { Intending Social } \\
\text { Sciences analytic } \\
\text { sample }(n=630)\end{array}$} \\
\hline & $\begin{array}{c}\text { Mean/ } \\
\text { proportion }\end{array}$ & (S.D.) & $\begin{array}{c}\text { Mean/ } \\
\text { proportion }\end{array}$ & (S.D.) \\
\hline \multicolumn{5}{|l|}{ MEDIATORS: Characteristics of Institutions } \\
\hline \multicolumn{5}{|l|}{ High school type (W1) } \\
\hline Public & 0.90 & & 0.87 & \\
\hline Catholic & 0.05 & & 0.06 & \\
\hline Other private & 0.05 & & 0.07 & \\
\hline First college is non-four year institution (W4) & & & 0.23 & \\
\hline \multicolumn{5}{|l|}{ Sector of first college (W4): } \\
\hline Public & & & 0.70 & \\
\hline Private, non-profit & & & 0.30 & \\
\hline Private, for-profit & & & 0.005 & \\
\hline \multicolumn{5}{|l|}{ Selectivity of first college (W4): } \\
\hline Non-selective & & & 0.31 & \\
\hline Medium selectivity & & & 0.35 & \\
\hline High selectivity & & & 0.33 & \\
\hline \multicolumn{5}{|l|}{ Controls } \\
\hline \multicolumn{5}{|l|}{ Race (W1) } \\
\hline White & 0.55 & & 0.47 & \\
\hline Black & 0.12 & & 0.11 & \\
\hline Latinx & 0.20 & & 0.30 & \\
\hline Asian & 0.05 & & 0.03 & \\
\hline Other & 0.08 & & 0.09 & \\
\hline Female (W1) & 0.52 & & 0.47 & \\
\hline Household income (W1, in units of $\$ 10,000)$ & 8.93 & $(0.31)$ & 9.66 & $(1.51)$ \\
\hline
\end{tabular}

Note: Cohort first surveyed as ninth graders in 2009 (Wave 1). Most were in 11th grade during Wave 2 (2012), and were approximately three years out of high school in Wave 4 license https://creativecommons.org/licenses/by-nc-nd/4.0/ 
Tilbrook, Ned, and Dara Shifrer. 2021. "Domain-Specific Cultural Capital and Persistence in College." Social Science Research Published online first.

Online Table 2: Odds Ratios from Logisitic Regression Models Predicting Selecting and Persisting with a College Social Sciences Major

\begin{tabular}{|c|c|c|c|c|c|c|}
\hline & \multicolumn{3}{|c|}{$\begin{array}{c}\text { Model } 1 \\
\text { Intention } \\
(n=12,730)\end{array}$} & \multicolumn{3}{|c|}{$\begin{array}{c}\text { Model } 2 \\
\text { Persistence } \\
(n=630)\end{array}$} \\
\hline & $\operatorname{Exp}(B)$ & & (SE) & $\operatorname{Exp}(B)$ & & (SE) \\
\hline \multicolumn{7}{|l|}{ Parents' Field-Specific Cultural Capital } \\
\hline Parent(s)' occupation is in social sciences (W1) & 1.82 & & 0.98 & 3.83 & & 3.76 \\
\hline \multicolumn{7}{|l|}{ Parents' educational attainment (W1): } \\
\hline No parent has bachelor's & - & & - & - & & - \\
\hline Parent(s) has a bachelor's, but not in social scien & 1.21 & & 0.23 & 1.06 & & 0.37 \\
\hline Parent(s) has bachelor's in social sciences & 1.93 & $*$ & 0.51 & 1.32 & & 0.66 \\
\hline \multicolumn{7}{|l|}{ Controls } \\
\hline \multicolumn{7}{|l|}{ Race (W1): } \\
\hline White & - & & - & - & & - \\
\hline Black & 1.11 & & 0.31 & 0.46 & & 0.23 \\
\hline Latinx & 2.14 & $* *$ & 0.60 & 0.80 & & 0.34 \\
\hline Asian & 0.85 & & 0.39 & 0.74 & & 0.65 \\
\hline Other & 1.24 & & 0.26 & 0.33 & $*$ & 0.15 \\
\hline Female (W1) & 1.18 & & 0.26 & 0.96 & & 0.36 \\
\hline Household income (W1, in units of $\$ 10,000)$ & 1.00 & & 0.01 & 1.00 & & 0.02 \\
\hline
\end{tabular}

Note: ${ }^{* *} p<0.001, * * p<0.01, * p<0.05$ 
Tilbrook, Ned, and Dara Shifrer. 2021. "Domain-Specific Cultural Capital and Persistence in College." Social Science Research Published online first.

Online Table 3, part 1 of 2: Descriptive Statistics, Core STEM Sensitivity Anlyses

\begin{tabular}{|c|c|}
\hline Intending College & Intending Core \\
\hline $\begin{array}{l}\text { Analytic Sample } \\
\qquad(n=12,730)\end{array}$ & $\begin{array}{c}\text { STEM analytic } \\
\text { sample }(n=2,620)\end{array}$ \\
\hline $\begin{array}{l}\text { Mean/ } \\
\text { proportion (S.D.) }\end{array}$ & $\begin{array}{l}\text { Mean/ } \\
\text { proportion (S.D.) }\end{array}$ \\
\hline
\end{tabular}

DEPENDENT VARIABLES: Social science Major Intentions and Persistence

Intended core STEM major (W3) 0.22

$\begin{array}{ll}\text { Persisted with core STEM major (W4) } & 0.74\end{array}$

PREDICTORS OF INTEREST: Parents' field-Specific Cultural Capital

\begin{tabular}{|c|c|c|c|c|}
\hline & \multicolumn{2}{|l|}{0.11} & \multirow{2}{*}{\multicolumn{2}{|c|}{0.16}} \\
\hline \multicolumn{3}{|l|}{ Parental education } & & \\
\hline Neither parent has bachelor's degree & \multicolumn{2}{|l|}{0.55} & \multicolumn{2}{|l|}{0.45} \\
\hline $\begin{array}{l}\text { Parent(s) has a bachelor's, but not a } \\
\text { core STEM bachelor's }\end{array}$ & \multicolumn{2}{|l|}{0.32} & \multicolumn{2}{|l|}{0.33} \\
\hline Parent(s) has a core STEM bachelor's & \multicolumn{2}{|l|}{0.13} & \multicolumn{2}{|l|}{0.21} \\
\hline \multicolumn{5}{|c|}{ MEDIATORS: Adolescent's STEM-Specific Embodied Cultural Capital } \\
\hline Math self-efficacy identity (W2) & 0.09 & $(0.02)$ & 0.56 & (0.04) \\
\hline Science self-efficacy identity (W2) & 0.05 & $(0.02)$ & 0.36 & $(0.03)$ \\
\hline Math utility value (W2) & 0.06 & $(0.02)$ & 0.32 & $(0.03)$ \\
\hline Science utility value (W2) & 0.04 & $(0.02)$ & 0.43 & (0.03) \\
\hline Expects STEM occupation at age 30 (W2) & 0.13 & & 0.34 & \\
\hline First postsecondary institution is non-four & ion $(\mathrm{V}$ & & 0.23 & \\
\hline \multicolumn{5}{|l|}{ Chose 2016 major beause (all W4): } \\
\hline Did well in that major's courses & & & 0.77 & \\
\hline was encouraged to choose major & & & 0.46 & \\
\hline
\end{tabular}

MEDIATORS: Adolescent's STEM-Specific Insitutional Cultural Capital

$\begin{array}{lll}\text { Advanced beyond algebra II (W3 transcript) } & 0.50 & 0.69\end{array}$

$\begin{array}{lll}\text { Earned high school physics credit (W3 transcript) } & 0.42 & 0.61\end{array}$

$\begin{array}{lllll}\text { High school STEM GPA } & 2.68 & (0.02) & 3.00 & (0.03)\end{array}$

\begin{tabular}{lllll} 
Math test score (W2) & 0.21 & $(0.03)$ & 0.72 & $(0.04)$ \\
\hline
\end{tabular} 
Tilbrook, Ned, and Dara Shifrer. 2021. "Domain-Specific Cultural Capital and Persistence in College." Social Science Research Published online first.

Online Table 3, part 2 of 2: Descriptive Statistics, Core STEM Sensitivity Anlyses

\begin{tabular}{|c|c|c|c|c|}
\hline & \multicolumn{2}{|c|}{$\begin{array}{c}\text { Intending College } \\
\text { Analytic Sample } \\
(n=12,730) \\
\end{array}$} & \multicolumn{2}{|c|}{$\begin{array}{c}\text { Intending Core } \\
\text { STEM analytic } \\
\text { sample }(n=2,620)\end{array}$} \\
\hline & $\begin{array}{c}\text { Mean/ } \\
\text { proportion }\end{array}$ & (S.D.) & $\begin{array}{c}\text { Mean/ } \\
\text { proportion }\end{array}$ & (S.D.) \\
\hline \multicolumn{5}{|l|}{ MEDIATORS: Characteristics of Institutions } \\
\hline \multicolumn{5}{|l|}{ High school type (W1) } \\
\hline Public & 0.90 & & 0.90 & \\
\hline Catholic & 0.05 & & 0.06 & \\
\hline Other private & 0.05 & & 0.04 & \\
\hline First college is non-four year institution (W4) & & & 0.23 & \\
\hline \multicolumn{5}{|l|}{ Sector of first college (W4): } \\
\hline Public & & & 0.78 & \\
\hline Private, non-profit & & & 0.20 & \\
\hline Private, for-profit & & & 0.01 & \\
\hline \multicolumn{5}{|l|}{ Selectivity of first college (W4): } \\
\hline Non-selective & & & 0.26 & \\
\hline Medium selectivity & & & 0.31 & \\
\hline High selectivity & & & 0.43 & \\
\hline \multicolumn{5}{|l|}{ Controls } \\
\hline \multicolumn{5}{|l|}{ Race (W1) } \\
\hline White & 0.55 & & 0.61 & \\
\hline Black & 0.12 & & 0.07 & \\
\hline Latinx & 0.20 & & 0.16 & \\
\hline Asian & 0.05 & & 0.08 & \\
\hline Other & 0.08 & & 0.08 & \\
\hline Female (W1) & 0.52 & & 0.34 & \\
\hline Household income (W1, in units of $\$ 10,000)$ & 8.93 & $(0.31)$ & 9.87 & $(0.39)$ \\
\hline
\end{tabular}
license https://creativecommons.org/licenses/by-nc-nd/4.0/ 
Tilbrook, Ned, and Dara Shifrer. 2021. "Domain-Specific Cultural Capital and Persistence in College." Social Science Research Published online first.

Online Table 4: Odds Ratios from Logisitic Regression Models Predicting Selecting and Persiting With a College Core STEM Major

\begin{tabular}{|c|c|c|c|c|c|}
\hline & \multicolumn{3}{|c|}{$\begin{array}{c}\text { Model } 1 \\
\text { Intention } \\
(n=12,730)\end{array}$} & \multicolumn{2}{|c|}{$\begin{array}{c}\text { Model } 2 \\
\text { Persistence } \\
(n=2,620)\end{array}$} \\
\hline & $\operatorname{Exp}(B)$ & & (SE) & $\operatorname{Exp}(B)$ & (SE) \\
\hline \multicolumn{6}{|l|}{ Parents' Field-Specific Cultural Capital } \\
\hline Parent(s)' occupation is in core STEM (W1) & 1.09 & & 0.12 & 1.38 & 0.35 \\
\hline \multicolumn{6}{|l|}{ Parents' educational attainment (W1): } \\
\hline No parent has bachelor's & - & & - & - & - \\
\hline Parent(s) has a bachelor's, but not in core STEM & 1.29 & $* *$ & 0.11 & 1.32 & 0.23 \\
\hline Parent(s) has bachelor's in core STEM & 2.26 & $* * *$ & 0.26 & $1.92 *$ & 0.49 \\
\hline \multicolumn{6}{|l|}{ Controls } \\
\hline \multicolumn{6}{|l|}{ Race (W1): } \\
\hline White & - & & - & - & - \\
\hline Black & 0.56 & $* *$ & 0.10 & 0.57 & 0.21 \\
\hline Latinx & 0.81 & & 0.11 & $0.65 *$ & 0.14 \\
\hline Asian & 1.74 & $* * *$ & 0.23 & 0.89 & 0.27 \\
\hline Other & 0.91 & & 0.13 & 0.91 & 0.25 \\
\hline Female (W1) & 0.38 & $* * *$ & 0.03 & 0.89 & 0.14 \\
\hline Household income (W1, in units of $\$ 10,000)$ & 1.00 & & 0.00 & 1.01 & 0.01 \\
\hline
\end{tabular}

Note: ${ }^{* *} p<0.001,{ }^{* *} p<0.01,{ }^{*} p<0.05$

47 C2021. This manuscript version is made available under the CC-BY-NC-ND 4.0 license https://creativecommons.org/licenses/by-nc-nd/4.0/ 
Tilbrook, Ned, and Dara Shifrer. 2021. "Domain-Specific Cultural Capital and Persistence in College." Social Science Research Published online first.

Online Table 5, part 1 of 2: Descriptive Statistics, Healthcare Sensitivity Anlyses

\begin{tabular}{|c|c|}
\hline Intending College & Intending Core \\
\hline $\begin{array}{l}\text { Analytic Sample } \\
\quad(n=12,730)\end{array}$ & $\begin{array}{c}\text { STEM analytic } \\
\text { sample }(n=2,050)\end{array}$ \\
\hline $\begin{array}{l}\text { Mean/ } \\
\text { proportion (S.D.) }\end{array}$ & $\begin{array}{l}\text { Mean/ } \\
\text { proportion (S.D.) }\end{array}$ \\
\hline
\end{tabular}

DEPENDENT VARIABLES: Social science Major Intentions and Persistence

Intended healthcare major (W4)

0.18

Persisted with healthcare major (W4)

0.64

PREDICTORS OF INTEREST: Parents' field-Specific Cultural Capital

\begin{tabular}{|c|c|c|c|c|}
\hline \multirow{2}{*}{\multicolumn{5}{|c|}{$\begin{array}{l}\text { Parent(s) has a healthcare occupation } \\
\text { Parental education }\end{array}$}} \\
\hline & & & & \\
\hline Neither parent has bachelor's degree & \multicolumn{2}{|l|}{0.55} & \multicolumn{2}{|l|}{0.62} \\
\hline $\begin{array}{l}\text { Parent(s) has a bachelor's, but not a } \\
\text { healthcare bachelor's }\end{array}$ & \multicolumn{2}{|l|}{0.39} & \multicolumn{2}{|l|}{0.30} \\
\hline Parent(s) has a healthcare bachelor's & \multicolumn{2}{|l|}{0.05} & \multicolumn{2}{|l|}{0.07} \\
\hline \multicolumn{5}{|c|}{ MEDIATORS: Adolescent's STEM-Specific Embodied Cultural Capital } \\
\hline Math self-efficacy identity (W2) & 0.09 & $(0.02)$ & 0.01 & $(0.04)$ \\
\hline Science self-efficacy identity (W2) & 0.05 & $(0.02)$ & 0.07 & $(0.04)$ \\
\hline Math utility value (W2) & 0.06 & $(0.02)$ & 0.12 & $(0.04)$ \\
\hline Science utility value (W2) & 0.04 & $(0.02)$ & 0.30 & $(0.04)$ \\
\hline Expects STEM occupation at age 30 (W2) & 0.13 & & 0.05 & \\
\hline \multicolumn{5}{|l|}{ Chose 2016 major beause (all W4): } \\
\hline Did well in that major's courses & & & 0.72 & \\
\hline was encouraged to choose major & & & 0.47 & \\
\hline \multicolumn{5}{|c|}{ MEDIATORS: Adolescent's STEM-Specific Insitutional Cultural Capital } \\
\hline Advanced beyond algebra II (W3 transcript) & 0.50 & & 0.48 & \\
\hline Earned high school physics credit (W3 transcript) & 0.42 & & 0.38 & \\
\hline High school STEM GPA & 2.68 & $(0.02)$ & 2.68 & $(0.03)$ \\
\hline Math test score (W2) & 0.21 & $(0.03)$ & 0.00 & $(0.03)$ \\
\hline
\end{tabular}


Tilbrook, Ned, and Dara Shifrer. 2021. "Domain-Specific Cultural Capital and Persistence in College." Social Science Research Published online first.

Online Table 5, part 2 of 2: Descriptive Statistics, Healthcare Sensitivity Anlyses

\begin{tabular}{|c|c|c|c|c|}
\hline & \multicolumn{2}{|c|}{$\begin{array}{c}\text { Intending College } \\
\text { Analytic Sample } \\
(n=12,730) \\
\end{array}$} & \multicolumn{2}{|c|}{$\begin{array}{l}\text { Intending Core } \\
\text { STEM analytic } \\
\text { sample }(n=2,050)\end{array}$} \\
\hline & $\begin{array}{c}\text { Mean/ } \\
\text { proportion }\end{array}$ & (S.D.) & $\begin{array}{c}\text { Mean/ } \\
\text { proportion }\end{array}$ & (S.D.) \\
\hline \multicolumn{5}{|l|}{ MEDIATORS: Characteristics of Institutions } \\
\hline \multicolumn{5}{|l|}{ High school type (W1) } \\
\hline Public & 0.90 & & 0.92 & \\
\hline Catholic & 0.05 & & 0.05 & \\
\hline Other private & 0.05 & & 0.04 & \\
\hline First college is non-four year institution (W4) & & & 0.41 & \\
\hline \multicolumn{5}{|l|}{ Sector of first college (W4): } \\
\hline Public & & & 0.75 & \\
\hline Private, non-profit & & & 0.21 & \\
\hline Private, for-profit & & & 0.04 & \\
\hline \multicolumn{5}{|l|}{ Selectivity of first college (W4): } \\
\hline Non-selective & & & 0.48 & \\
\hline Medium selectivity & & & 0.33 & \\
\hline High selectivity & & & 0.19 & \\
\hline \multicolumn{5}{|l|}{ Controls } \\
\hline \multicolumn{5}{|l|}{ Race (W1) } \\
\hline White & 0.55 & & 0.50 & \\
\hline Black & 0.12 & & 0.15 & \\
\hline Latinx & 0.20 & & 0.21 & \\
\hline Asian & 0.05 & & 0.04 & \\
\hline Other & 0.08 & & 0.10 & \\
\hline Female (W1) & 0.52 & & 0.10 & \\
\hline Household income (W1, in units of $\$ 10,000)$ & 8.93 & $(0.31)$ & 8.35 & $(0.52)$ \\
\hline
\end{tabular}

49 (C2021. This manuscript version is made available under the CC-BY-NC-ND 4.0 license https://creativecommons.org/licenses/by-nc-nd/4.0/ 
Tilbrook, Ned, and Dara Shifrer. 2021. "Domain-Specific Cultural Capital and Persistence in College." Social Science Research Published online first.

Online Table 6: Odds Ratios from Logisitic Regression Models Predicting Selecting and Persiting With a College Healthcare Major

\begin{tabular}{|c|c|c|c|c|c|c|}
\hline & \multicolumn{3}{|c|}{$\begin{array}{c}\text { Model } 1 \\
\text { Intention } \\
(n=12,730)\end{array}$} & \multicolumn{3}{|c|}{$\begin{array}{c}\text { Model } 2 \\
\text { Persistence } \\
(n=2,050)\end{array}$} \\
\hline & $\operatorname{Exp}(B)$ & & (SE) & $\operatorname{Exp}(B)$ & & (SE) \\
\hline \multicolumn{7}{|l|}{ Parents' Field-Specific Cultural Capital } \\
\hline Parent(s)' occupation is in healthcare (W1) & 1.45 & $*$ & 0.16 & 1.00 & & 0.24 \\
\hline \multicolumn{7}{|l|}{ Parents' educational attainment (W1): } \\
\hline No parent has bachelor's & 0.68 & $* * *$ & 0.07 & 0.90 & & 0.16 \\
\hline Parent(s) has a bachelor's, but not in healthcare & 0.68 & $* * *$ & 0.07 & 0.90 & & 0.16 \\
\hline Parent(s) has bachelor's in healthcare & 1.13 & & 0.27 & 1.28 & & 0.43 \\
\hline \multicolumn{7}{|l|}{ Controls } \\
\hline \multicolumn{7}{|l|}{ Race (W1): } \\
\hline \multicolumn{7}{|l|}{ White } \\
\hline Black & 1.35 & $*$ & 0.19 & 0.61 & $*$ & 0.13 \\
\hline Latinx & 1.16 & & 0.15 & 0.64 & & 0.15 \\
\hline Asian & 1.02 & & 0.21 & 0.72 & & 0.22 \\
\hline Other & 1.16 & & 0.21 & 1.44 & & 0.36 \\
\hline Female (W1) & 3.87 & $* * *$ & 0.42 & 2.12 & $* * *$ & 0.36 \\
\hline Household income (W1, in units of $\$ 10,000)$ & 1.00 & & 0.00 & 0.99 & & 0.01 \\
\hline
\end{tabular}

